\section{A) Check for updates}

Cite this: Food Funct., 2021, 12, 7527

\title{
Dry-heat processing at different conditions impact the nutritional composition and in vitro starch and protein digestibility of immature rice-based products
}

\author{
Kulwa F. Miraji, (D) ${ }^{\text {a,b }}$ Anita R. Linnemann, ${ }^{b}$ Vincenzo Fogliano, (D) ${ }^{\text {b Henry S. Laswai }}{ }^{\mathrm{c}}$ \\ and Edoardo Capuano (D)*b
}

\begin{abstract}
Immature grain represents a precious nutritional source in many rural Africa areas. To optimize processing of immature rice into pepeta (a traditional rice-flakes produced from immature rice grains), immature rice (TXD306 variety) harvested at 18 and 26 days after 50\% heading were processed in the laboratory under different soaking $(0$ and $12 \mathrm{~h})$ and roasting temperature $\left(80,100\right.$ and $\left.120^{\circ} \mathrm{C}\right)$ regimes. Riboflavin, nicotinic acid, nicotinamide and iron concentration increased with severity of roasting temperature, while thiamine has an opposite trend. Heating promoted the transformation of insoluble into soluble dietary fiber, increased lipid digestibility decreasing protein one, which showed the highest value when rice was roasted at $100{ }^{\circ} \mathrm{C}$. Soaking before roasting significantly increased moisture and iron content while slightly increased riboflavin, nicotinic acid and nicotinamide when compared to unsoaked products. Among roasted products, starch digestibility increased with roasting temperature. Microstructure analysis indicated a complete loss of cell wall integrity in cooked rice, determining a complete starch and protein digestion while this is delayed in raw rice and roasted products. We concluded that roasting at $100{ }^{\circ} \mathrm{C}$ is the optimum temperature to produce pepeta of the highest protein digestibility and low starch digestibility. Soaking before roasting at $120^{\circ} \mathrm{C}$ is best when retaining micronutrients is considered.
\end{abstract}

\begin{abstract}
Received 21st April 2021, Accepted 21st June 2021

DOI: $10.1039 / \mathrm{d} 1 \mathrm{fo} 01240 \mathrm{a}$

rsc.li/food-function
\end{abstract}

\section{Introduction}

Consumption of immature cereal-based products is common in communities where cereals are staple food. Firik (also known as frikeh or frekeh or freekah) is a scorched/roasted immature whole wheat-based food consumed in Arabic countries in the Middle East and Northern Africa. ${ }^{1-4}$ Breads prepared from green maize and sorghum kernels are widely consumed in sub-Saharan Africa. ${ }^{5}$ In Tanzania, pepeta, a locally prepared rice flakes from immature grains, is common among rice consuming communities. ${ }^{6,7}$ Currently, consumption of immature cereal-based products is gaining popularity worldwide due to their nutritional and health potential benefits compared to fully mature cereal grains. Nutritional components such as protein, reducing sugars, calcium, potassium, iron, $\beta$-carotene, vitamin $\mathrm{C}$, and vitamin $\mathrm{B} 2$, $\mathrm{B} 3$ and $\mathrm{B}^{7-9}$ and functional compounds like dietary fiber, fructooligosaccharides and phytochemicals (phenolics and

\footnotetext{
${ }^{a}$ Tanzania Agricultural Research Institute, Ifakara Centre, Ifakara, Tanzania

${ }^{b}$ Food Quality and Design, Wageningen University and Research, Wageningen, The Netherlands.E-mail: edoardo.capuano@wur.nl

${ }^{c}$ Mwenge Catholic University, Moshi, Tanzania
}

flavonoids) $)^{1,3,10,11}$ decrease as cereal grain mature. These variations are the physiological consequences of cellular and physiological changes during grain development. ${ }^{12}$

However, the processing of some immature cereal-based products like pepeta is still done only at the household level. The production process is slow, labor intensive, with no established standards for harvesting, processing conditions and parameters. ${ }^{6}$ This makes it impossible to guarantee a consistently good quality pepeta product and hinders its upscaling to the industrial production level.

Despite the valuable content of micronutrients pepeta, like that of cooked milled white rice, has a very high and fast starch digestibility properties. ${ }^{6}$ Fast and high starch digestibility has been linked to high glycemic index (GI), associated with high occurrence of type II diabetes. ${ }^{13-15}$ On the contrary, consumption of rice-based products with high digestible proteins can help improve the nutritional status (i.e. proteinenergy malnutrition) of populations, as rice is the staple food and widely available and affordable for most of the population. ${ }^{16}$ In this framework, the main goal is to design cereal food products with high protein and low starch digestibility. In order to improve the nutritional quality and functional properties of the immature cereal-based product, insight into the 
changes in nutritional composition and digestibility properties of immature rice grains processed at different conditions is inevitable. This study focused on pepeta and simulated its production in the laboratory using different soaking and temperature regimes to optimize its processing conditions. The effect of soaking and roasting treatments on nutritional content and in vitro digestion of starch and protein and their interaction was evaluated. The difference in nutritional content and in vitro digestion of starch and protein between maturity levels were assessed as well to validates our previous findings as paddy grains were harvested at specific maturity date. Contrast to this study, paddy grains in the previous findings ${ }^{7}$ were harvested according to processors knowledge, then their maturity levels classified into categories which could have produced artefacts due to minimum and maximum extremes of individual maturity levels withing category.

\section{Materials and methods}

\subsection{Materials}

2.1.1. Rice. Immature rice grains (at $31-43 \%$ moisture content) of TXD306 variety suit for pepeta production were collected from a rice farmer at Ulanga district in Tanzania and used as research materials in this study. The grains were harvested at 18 and 26 days after 50\% heading (DAH), based on our previous study that reported 15-28 DAH as the optimum maturity for pepeta production. ${ }^{6}$ The heading date (at 50\% heading) was determined when 50 percent of the panicles in the rice field were at least partially visible. For each maturity level, $5 \mathrm{~kg}$ of harvested wet rice grains (in portions of $500 \mathrm{~g}$ ) were vacuum-sealed in plastic bags (Princess ${ }^{\circledR}$, S-492967-001, China) and stored at $-20^{\circ} \mathrm{C}$ until further use.

2.1.2. Reagent. Pepsin from porcine gastric mucosa (P6887, 3200-4500 $\mathrm{U} \mathrm{mg}^{-1}$ ), porcine bile extract (B8631), amyloglucosidase from Aspergillus niger (10113, $129.3 \mathrm{U} \mathrm{mg}^{-1}$ ), trypsin from porcine pancreas (T7409, 1000-2000 $\mathrm{U} \mathrm{mg}^{-1}$ ), $\alpha$-chymotrypsin from bovine pancreas (C4129, $\geq 40 \mathrm{U} \mathrm{mg}^{-1}$ ), $\alpha$-amylase from porcine pancreas (A4268, 700-1400 $\mathrm{U} \mathrm{mg}^{-1}$ ), sodium dodecyl sulfate (SDS), o-phthaldialdehyde (OPA), DL-dithiothreitol (DTT), L-serine, thiamine hydrochloride (B1), nicotinic acid (B3, $\geq 99.5 \%$ HPLC), and nicotinamide (B3) were purchased from Sigma-Aldrich Ltd (St Louis, MO, USA). Trichloroacetic acid (CAS 76-03-9) and disodium tetraborate decahydrate (CAS 130396-4) were bought from Merck \& Co. (Darmstadt, Germany). Assay kits for total starch, resistant starch, amylose/amylopectin, D-glucose (GOPOD) and dietary fiber analyses were acquired from Megazyme Inc. (Wicklow, Ireland). Other chemicals used in this study were of analytical grade.

\subsection{Preparation of immature rice-based products}

Immature harvested rice grains were roasted in the laboratory, mimicking pepeta processing technology, using various soaking and temperature regimes, as shown in Fig. 1A and B. Before roasting, one-half of the frozen paddy grains samples were kept at room temperature $\left(20-25^{\circ} \mathrm{C}\right)$ for 12 hours until their temperature equilibrated to that of the surroundings, whereas the second half was soaked in cold water at room temperature overnight (12 hours) and left to drain-off water for 6 hours. Replicate samples $(100 \mathrm{~g})$ of soaked and unsoaked paddy grains were each roasted at 80,100 and $120{ }^{\circ} \mathrm{C}$ for 8 minutes using hot air fluidized roaster (Toper, Optical Coffee Roaster, Turkey). For each temperature, three independent samples were roasted. Once roasted, the samples were cooled down to room temperature before milling into rice grains using a milling machine (F. Walter - H. Wintersteiger K. G. Maschinen-Geratebau, Ried Innkreis, Austria) for 4 minutes. The machine employs single-stage milling technology whereby dehulling and polishing of paddy grain is done concurrently. Tiny broken kernels, tips and fine powder were removed using a $2 \mathrm{~mm}$ sieve, while brans, rice straws, and other light chaffs were removed by blower system (Herding Filertechnik, HSL 1500-14-16/18 SB, German) set at $180 \mathrm{daPa}$. The milling machine was cleaned using compressed air (Kaeser Kompressoren, SM 12 SIGMA, Netherlands) set at 7.2-7.8 bar before milling another sample. Samples were then stored at $-20{ }^{\circ} \mathrm{C}$ for further laboratory analyses.

Three control samples were also assessed: (i) raw rice - a portion $(500 \mathrm{~g})$ of immature harvested rice variety TXD306 that had been dried to $13-11 \%$ using a hot air dryer (TG 200, Retsch $\mathrm{GmbH}$, Haan, Germany) set at $50{ }^{\circ} \mathrm{C}$ and milled into white rice for 2 minutes, not roasted; (ii) pepeta - a locally prepared pepeta from corresponding fresh harvested rice variety TXD306 that has been manually roasted on an open wood fire (181-270 ${ }^{\circ} \mathrm{C}$, paddy temperature $80-129{ }^{\circ} \mathrm{C}$ ) for $3-8 \mathrm{~min}$, immediately followed by hand pounding using a pestle and mortar for 1-3 min, as described in our previous study; ${ }^{6,7}$ and (iii) cooked rice - a portion (10 g) of milled raw rice sample used for determination of starch properties, microstructure and in vitro digestion analyses only, that had been well cooked in excess boiling water (ratio $1: 25 \mathrm{w} / \mathrm{v}$, respectively) until fully gelatinized. Cooked rice kernels were pressed between two glass slides to check for optimum gelatinization, i.e., when no clear white core was observed anymore. The processing treatments were assigned codes (Fig. 1A), indicating roasting temperature $\left({ }^{\circ} \mathrm{C}\right)$ and soaking time $(\mathrm{h})$ for the laboratory simulated pepeta processing treatments.

2.2.1. Grinding. A cryo-mill (Freezer mill 6875D, Spex Sample Perp) was used to mill raw milled white rice, pepeta and roasted rice products set at 2 cycles, 2 min cooling, 5 min grinding, and 15 cycles per second (cps). The retained flour particles (425-250 $\mu \mathrm{m})$ were used in microstructure and in vitro digestion analyses, whereas the particles that passed through $250 \mu \mathrm{m}$ laboratory sieve were used for other analyses. For cooked samples, cooked rice grains were squeezed through a $425 \mu \mathrm{m}$ laboratory sieve and used for starch properties, microstructure and in vitro digestion analyses. Samples were immediately stored at $-20^{\circ} \mathrm{C}$ till further uses.

\subsection{Proximate analysis}

Dry matter content was determined by oven drying $2 \mathrm{~g}$ of samples overnight set at $105{ }^{\circ} \mathrm{C}$ and the weight difference cal- 

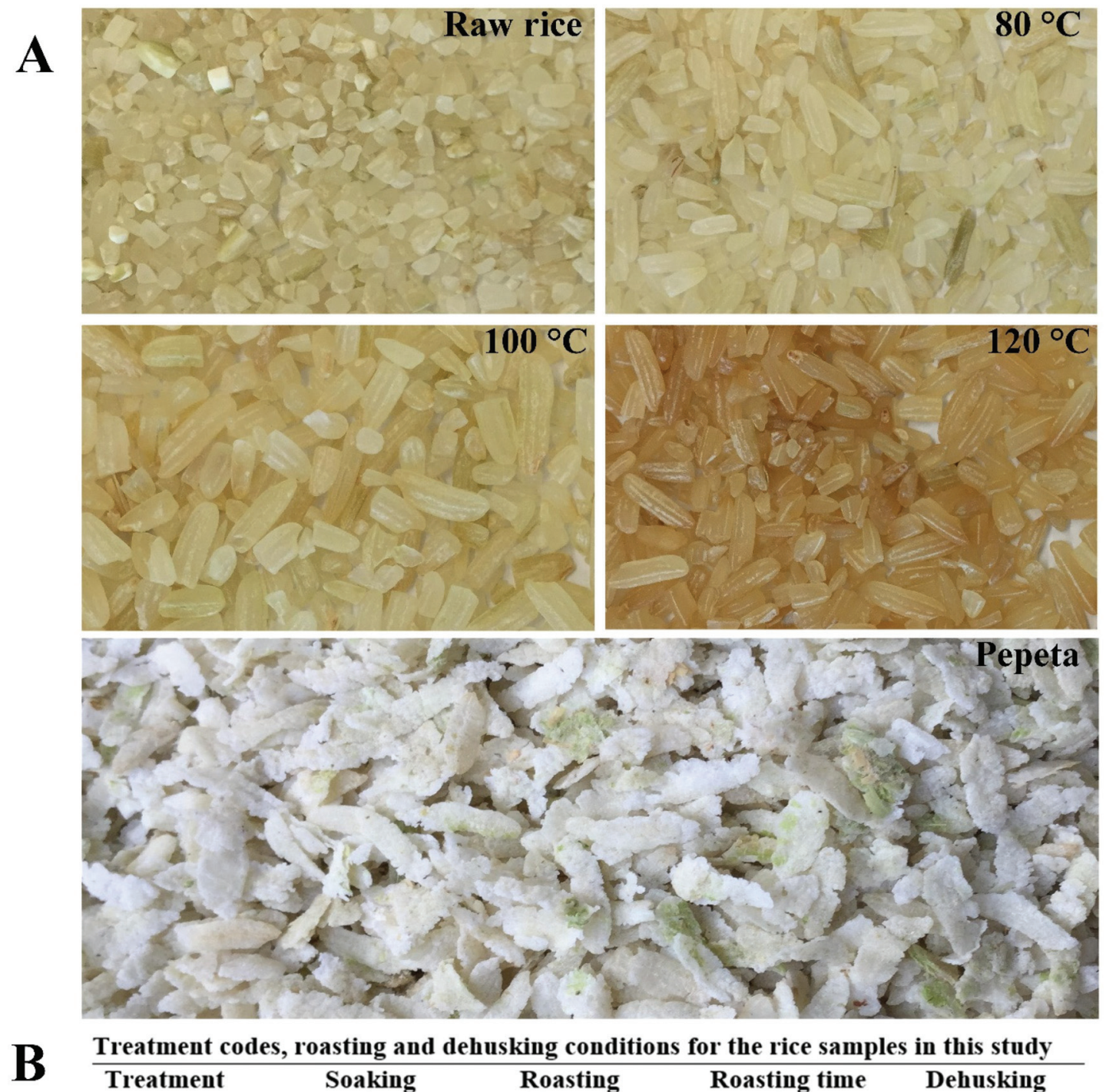

Treatment codes, roasting and dehusking conditions for the rice samples in this study

\begin{tabular}{lcccc}
\hline $\begin{array}{l}\text { Treatment } \\
\text { code }\end{array}$ & $\begin{array}{c}\text { Soaking } \\
\text { time (h) }\end{array}$ & $\begin{array}{c}\text { Roasting } \\
\text { temperature }\left({ }^{\circ} \mathbf{C}\right)\end{array}$ & $\begin{array}{c}\text { Roasting time } \\
(\text { min) }\end{array}$ & $\begin{array}{c}\text { Dehusking } \\
\text { time (min) }\end{array}$ \\
\hline $80-\mathrm{NS}$ & 0 & 80 & 8 & 4 \\
$80-\mathrm{S}$ & 12 & 80 & 8 & 4 \\
$100-\mathrm{NS}$ & 0 & 100 & 8 & 4 \\
$100-\mathrm{S}$ & 12 & 100 & 8 & 4 \\
$120-\mathrm{NS}$ & 0 & 120 & 8 & 4 \\
$120-\mathrm{S}$ & 12 & 120 & 8 & 4 \\
Raw rice* & & Immature dried paddy & & $2 *$
\end{tabular}

Pepeta Locally prepared pepeta from fresh harvested immature paddy

*Raw rice samples were less hard compared to roasted rice samples, thereby dehusking beyond 2 minutes cause substantial sample losses in form of flour dust mixed with bran. NS - not soaked, $\mathrm{S}$ - soaked in cold water for $12 \mathrm{~h}$ before roasting, 80,100 and 120 are corresponding roasting temperatures $\left({ }^{\circ} \mathrm{C}\right)$.

Fig. 1 General appearance of raw and processed rice samples at different roasting temperatures (A), and tabulation description (B) of laboratory experiment design employed in this study.

culated according to an AOAC method. ${ }^{17}$ To quantify ash content, $2 \mathrm{~g}$ of samples were incinerated at $550{ }^{\circ} \mathrm{C}$ overnight following AOAC methods. ${ }^{17}$ Soxhlet-petroleum ether extraction system was used to extract fat from $5 \mathrm{~g}$ of the sample according to an AOAC method. ${ }^{17}$ The extracted fat was then expressed as the mass percentage of the original sample. Dumas combustion method was used to estimate the nitrogen content. About 15-20 mg of sample was analyzed (EA 1112 NC, Thermo fisher 
scientific Inc., Waltman, USA) following the manufacturer's protocol. D-Methionine and cellulose were used to prepare the calibration curve and as control, respectively. To convert nitrogen content to protein, a specific conversation factor (Jones factor for rice products) of 5.95 was used. ${ }^{18}$ Total carbohydrate content was calculated by the subtraction method, i.e., the fraction retained after deduction of other proximate compositions on a dry matter basis.

\subsection{Degree of milling}

The degree of milling (DOM) was estimated by the surface lipid content (SLC) method according to Matsler and Siebenmorgen $^{19}$ using soxhlet-petroleum ether extraction system as described in section 2.3. Whole kernels of pepeta and roasted products, and large broken grains (above $2 / 3$ of the original size) of raw rice (due to lack of whole kernels), were used in this analysis.

\subsection{Crude dietary fiber}

The enzymatic gravimetric method using a megazymes kit (K-TDFR, Megazyme Int, Wicklow, Ireland) was employed to determine Soluble (SDF) and insoluble (IDF) dietary fiber. In summary, the mixture of the sample (1 g) and MES-TRIS buffer solution $(40 \mathrm{~mL})$ was incubated in series with $\alpha$-amylase, protease, and amyloglucosidase enzymes before being filtering to obtain the IDF. For SDF quantification, hot ethanol $(95 \%, \mathrm{v} / \mathrm{v})$ at $60{ }^{\circ} \mathrm{C}$ was used to precipitate the filtrate. SDF and IDF values were corrected by subtracting the corresponding ash and protein residuals. Total dietary fiber (TDF) was determined as the sum of SDF and IDF.

\subsection{Analysis of $\mathrm{Fe}$ and $\mathrm{Zn}$}

ICP-AES (Inductively Coupled Plasma - Atomic Emission Spectrometry) using Thermo iCAP-6500 DV equipment (Thermo Fisher Scientific, Waltham, USA) was employed to estimate the content of $\mathrm{Fe}$ and $\mathrm{Zn}$, as described in our previous study. ${ }^{7}$ In summary, $300 \mathrm{mg}$ of flour sample was digested with the concentrated nitric-hydrochloric acid mixture and hydrogen-peroxide in series ${ }^{20}$ before analyzed on ICP-AES. The flour samples were dried at $70{ }^{\circ} \mathrm{C}$ overnight before the analysis.

\subsection{Determination of vitamin B1, B2 and B3}

The determination of thiamine, riboflavin, nicotinic acid and nicotinamide was done following the modified procedure of Chen et al. ${ }^{21}$ To extracts B vitamins, mixtures of $0.5 \mathrm{~g}$ ground samples with $25 \mathrm{~mL}$ milli Q water in $50 \mathrm{~mL}$ grainer tubes were sonicated at $40{ }^{\circ} \mathrm{C}$ for $5 \mathrm{~h}$ before centrifuging at $3000 \mathrm{~g}$ for $10 \mathrm{~min}$ at room temperature. A $0.2 \mu \mathrm{m}$ membrane filter was used to filter the supernatant, and $20 \mu \mathrm{L}$ extract was used for HPLC analysis. For thiamine, nicotinic acid and nicotinamide quantification, the mobile phase was $25 \mathrm{mM} \mathrm{KH}_{2} \mathrm{PO}_{4}(\mathrm{pH}$ 3): $\mathrm{CNCH}_{3}$ in a ratio of $97: 3$. Riboflavin was analyzed using $5 \mathrm{mM}$ ammonium formate buffer/acetonitrile buffer in a ratio of 70 to 30 , respectively. The HPLC system was operated with a Prevail C18 column $(5 \mu \mathrm{m}, 4.6 \times 250 \mathrm{~mm})$, at a flow rate of
$1.0 \mathrm{~mL} \mathrm{~min}^{-1}$ and a UV detector set at 245 and $270 \mathrm{~nm}$ at room temperature.

\subsection{Starch characterization analysis}

2.8.1. Total, resistant and digestible starch. Resistant starch (RS) and digestible starch (DS) were evaluated by an enzymatic gravimetric method using a commercial Megazyme kit (K-RSTAR 05/19, Megazyme Int., Wicklow, Ireland). Cooked rice products containing higher moisture (80-84\% wet basis) were treated as wet samples. Total starch (TS) was calculated as the sum of resistant starch and non-resistant (digestible) starch.

2.8.2. Starch isolation and preparation of cooked starch. Isolation of starch was performed according to the modified wet-milling method described in Syahariza et $a .^{22}$ In brief, a rice slurry was prepared by milling for 10 minutes, a $50 \mathrm{~g}$ sample of soaked rice grains in sodium metabisulfite $(150 \mathrm{~mL}$, $0.45 \% \mathrm{w} / \mathrm{v}$ ) for 72 hours at $4{ }^{\circ} \mathrm{C}$ using a commercial blender. To remove protein, the slurry was repeatedly and vigorously mixed with $450 \mathrm{~mL} \mathrm{NaCl}(0.1 \mathrm{M})$ solution and $50 \mathrm{~mL}$ toluene was employed till the toluene layer was clear and free from protein. The starch was then recovered by filtrating through a filter paper (Whatman $595 \frac{1}{2}$, Whatman International Ltd, Kent, UK), rinsed with $96 \%$ ethanol and left at room temperature for 2 hours to allow complete evaporation of ethanol before storing at $-20{ }^{\circ} \mathrm{C}$ for further analysis. To prepare cooked rice starch, $1 \mathrm{~g}$ from raw rice starch was dispersed in $4 \mathrm{~g}$ distilled water and incubated at $70{ }^{\circ} \mathrm{C}$ for $10 \mathrm{~min}$ with constant shaking $(200 \mathrm{rpm})$. Samples were then placed in a boiling water bath for $30 \mathrm{~min}$. To avoid retrogradation, the cooked starch pastes were immediately stored at $-20{ }^{\circ} \mathrm{C}$ till further analysis.

2.8.3. Amylose/amylopectin ratio. The amylose/amylopectin megazyme kit (K-AMYL 06/18, Megazyme Int., Wicklow, Ireland) was used to quantify the amylose content of processed rice flour and starch samples. Indirect measurement of amylopectin content was done by subtracting the amylose percentage from the TS percentage of the samples.

\subsection{Protein aggregations analysis}

2.9.1. Protein solubility. A solvent dependent solubility test on $26 \mathrm{DAH}$ samples was used to evaluate changes in protein interactions according to the modified protocol of Liu and Hsieh $^{23}$ and Van Der Borght. ${ }^{24}$ Four different solvents were used to extract protein; solvent 1 (S1, $0.1 \mathrm{M}$ phosphate buffer salt (PBS) at pH 7.5), solvent 2 (S2, $0.1 \mathrm{PBS} / 2 \%(\mathrm{w} / \mathrm{v})$ sodium dodecyl sulphate (SDS) at $\mathrm{pH} 7.5$ ), solvent 3 (S3, $0.1 \mathrm{PBS} / 2 \%$ (w/v) SDS/6 M urea at $\mathrm{pH} 7.5$ ), and solvent 4 (S4, $0.1 \mathrm{PBS} / 2 \%$ (w/v) SDS/6 M urea/1\% (w/v) dithiothreitol (DTT) at $\mathrm{pH} 7.5$ ). Flour samples (<250 mm sieve) were mixed with solvent in a ratio of $1: 25(\mathrm{w} / \mathrm{v})$, respectively and shaken for $1 \mathrm{~h}$ at $150 \mathrm{rpm}$ and $25{ }^{\circ} \mathrm{C}$. Subsequently, the solutions were centrifuged (4816g, 15 minutes, $25^{\circ} \mathrm{C}$ ) to recover the solubilized protein in the supernatants. Before extraction, each flour sample was freeze-dried, defatted with petroleum ether (soxhlet system) heated at $60{ }^{\circ} \mathrm{C}$ for $6 \mathrm{~h}$, and recovered flour in the soxhlet 
thimble was air-dried at $25{ }^{\circ} \mathrm{C}$ under a fume hood. The protein content of the supernatants was determined using a Pierce BCA protein assay kit (Thermo Fisher Scientific, Massachusetts, USA). The total protein content of protein samples was measured by the Dumas combustion method using the analyzer (EA 1112 NC, Thermo fisher scientific Inc., Waltman, USA) (section 2.3). The protein solubility was calculated as the percentage of protein in the supernatant to the protein in samples.

2.9.2. Free-thiol content. Free thiol content was determined according to the method described by Chan and Wasserman ${ }^{25}$ with modifications. In brief, flour samples $(75 \mathrm{mg}$ ) were suspended in $1.0 \mathrm{~mL}$ reaction buffer composed of $8 \mathrm{M}$ urea, $1 \%$ (w/v) SDS, 3 mM EDTA (ethylene-diaminetetraacetic acid) and $0.2 \mathrm{M}$ Tris-HCl, $\mathrm{pH}$ 8.0. Samples were incubated at $21^{\circ} \mathrm{C}$ for $1 \mathrm{~h}$ with intermittent shaking. Subsequently, samples were centrifuged at $10000 \mathrm{~g}$ for 10 minutes. From the supernatant, $50 \mu \mathrm{L}$ was taken and mixed with $950 \mu \mathrm{L}$ of $0.1 \mathrm{mM}$ DTNB working solution, prepared by dissolving $40 \mathrm{mg}$ DTNB (5,5-dithiobis (2-nitrobenzoic acid)) in $10 \mathrm{~mL}$ DMSO (dimethyl sulfoxide), followed by 100 -fold dilution with $0.1 \mathrm{M}$ Tris-HCl, $\mathrm{pH}$ 7.5. A blank was set by adding $50 \mu \mathrm{L} 0.1 \mathrm{M}$ Tris-HCL buffer to $950 \mu \mathrm{L}$ DTNB working solution. Absorbance was read with a spectrophotometer at $412 \mathrm{~nm}$, and free thiol content was calculated using the molar extinction coefficient of NTB $\left(14150 \mathrm{M}^{-1} \mathrm{~cm}^{-1}\right)$.

2.9.3. Total thiol content. The disulphide content was determined according to Thannhauser et $a{ }^{26}$ with slight modifications. $50 \mathrm{mg}$ of flour sample was dissolved in $1 \mathrm{~mL}$ reaction buffer, then diluted with $0.1 \mathrm{M}$ Borate buffer $\mathrm{pH} 9.0$ to obtain the concentration range of $5-0.5 \mathrm{mg} \mathrm{mL}^{-1}$ flour in solution. The reaction buffer was prepared by mixing 20 parts of the stock solution (6.3 M guanidine- $\mathrm{HCl}, 1 \mathrm{mM}$ EDTA, $0.2 \mathrm{M}$ Tris-CL, $\mathrm{pH}$ 9.5) and 1 part of the $2 \mathrm{M} \mathrm{Na}_{2} \mathrm{SO}_{3}$ solution. Subsequently, samples were centrifuged at $10000 \mathrm{~g}$ for 10 minutes. Thiols were determined by adding $10 \mu \mathrm{L}$ sample aliquot to $3 \mathrm{~mL}$ of $50 \mathrm{mM}$ NTSB (2-nitro 5-thio sulfo benzoic acid) solution, synthesized by dissolving $29.8 \mathrm{mg}$ DTNB in $3 \mathrm{~mL} 1 \mathrm{M} \mathrm{Na}_{2} \mathrm{SO}_{3} \mathrm{pH}$ 9-9.5 solution. The reaction mixture was then incubated at room temperature $\left(21^{\circ} \mathrm{C}\right)$ in the dark for 25 minutes. Absorption was read at $412 \mathrm{~nm}$, and disulphide content was calculated using the Extinction coefficient 13.600 $\mathrm{M}^{-1} \mathrm{~cm}^{-1}$ per disulphide. ${ }^{27}$ The same concentration range without added sample was made as a reference.

2.9.4. Surface hydrophobicity. Surface hydrophobicity $\left(H_{0}\right)$ was determined following the method described by Wang et $a{ }^{28}{ }^{28}$ using $8 \mathrm{mM}$ 1-anilino-8-naphthalene sulfonate as the hydrophobic fluorescence probes with modification. Defatted flour samples were prepared at a protein concentration (on a dry matter flour basis) of $5 \mathrm{mg} \mathrm{mL}^{-1}$ in a $0.01 \mathrm{M}$ phosphate buffer ( $\mathrm{pH} 7$ ), stirred at room temperature for $1 \mathrm{~h}$ and centrifuged $5000 \mathrm{~g}$ for $30 \mathrm{~min}$. The supernatants were serially diluted with the same buffer to various protein concentrations ranging from 0.5 to $0.005 \mathrm{mg} \mathrm{mL}{ }^{-1}$. Subsequently, $25 \mu \mathrm{L}$ of ANSA (8.0 $\mathrm{mM}$ in $0.1 \mathrm{M}$ phosphate buffer, $\mathrm{pH}$ 7) was added to $2.7 \mathrm{~mL}$ sample. The fluorescence intensity (FI) was measured by the LS50B luminescence spectrometer (PerkinElmer,
Massachusetts, USA) at $338 \mathrm{~nm}$ (excitation) and $496 \mathrm{~nm}$ (emission) wavelengths. The slope (linear regression fit) of the FI versus the protein concentration of the sample gave the protein surface hydrophobicity.

\subsection{In vitro digestion}

A two-phase gastro-intestinal in vitro starch and protein hydrolysis was employed following a modified consensus INFOGEST protocol $^{29}$ as described in our previous study. ${ }^{6}$ Before analysis, all samples (except cooked rice) were mixed with Milli-Q water in a ratio of $1: 2(\mathrm{w} / \mathrm{v})$, respectively. In all samples, a pre-warmed simulated salivary fluid (SSF) without salivary $\alpha$-amylase was added to a final ratio of $1: 1(\mathrm{w} / \mathrm{v})$, respectively. Immediately, the mixture was combined with simulated gastric fluids (SGF) and freshly prepared pepsin to a final ratio of food to SGF of $1: 1$ $(\mathrm{v} / \mathrm{v})$ and enzyme activity of $2000 \mathrm{U} \mathrm{mL}^{-1}$, respectively. The $\mathrm{pH}$ of the mixture was adjusted to 3 with $1 \mathrm{M} \mathrm{HCl}$ before the gastric digestion was simulated by incubating sample tubes at $37{ }^{\circ} \mathrm{C}$ for $120 \mathrm{~min}$. Thereafter, the gastric chyme was mixed with warmed simulated intestinal fluids (SIF) in a final ratio of $1: 1$ $(\mathrm{v} / \mathrm{v})$ to simulate the intestinal phase, respectively. Fresh bile and pancreatin solution were added by considering the final concentration of $28.8 \mathrm{mg} \mathrm{mL}^{-1}$ and trypsin enzymatic activity of $100 \mathrm{U} \mathrm{mL}^{-1}$, respectively. The chyme $\mathrm{pH}$ was adjusted to 7 with $1 \mathrm{M} \mathrm{NaOH}$ and incubated at $37^{\circ} \mathrm{C}$ for $120 \mathrm{~min}$ to complete a $240 \mathrm{~min}$ in vitro digestion.

The experiments were performed in an oven by placing sample tubes in a rotor (Multi Rs-60, Biosan, Riga, Latvia) set at $40 \mathrm{rpm}$. For each sample tubes, an aliquot sample $(0.2 \mathrm{~mL})$ were sampled at $0,60,120,125,130,140,150,180$ and $240 \mathrm{~min}$ for starch hydrolysis, and at 0, 60, 120, 150, 180 and $240 \mathrm{~min}$ for protein hydrolysis. Immediately, absolute ethanol and $20 \%$ TCA were separately added to the aliquot samples in the Eppendorf tubes to a ratio of 1:4 (in both starch and protein) to stop amylase and protease activity, respectively. The aliquots sample mixtures were left to cool at room temperature for $20 \mathrm{~min}$ before centrifuging at $3000 \mathrm{~g}$ for $10 \mathrm{~min}$ at $0{ }^{\circ} \mathrm{C}$. Subsequently, the supernatants were obtained in the new Eppendorf tubes and stored at $-20^{\circ} \mathrm{C}$ until further analysis.

2.10.1. Determination of starch hydrolysis. A mixture of $0.5 \mathrm{~mL}$ amyloglucosidase solution $\left(27.17 \mathrm{U} \mathrm{mL}^{-1}\right)$ in $0.1 \mathrm{M}$ sodium acetate buffer ( $\mathrm{pH} 4.8)$ and $0.1 \mathrm{~mL}$ ethanolic supernatant obtained after the termination of amylase activity were incubated at $37^{\circ} \mathrm{C}$ for $1 \mathrm{~h}$. To quantify the amount of glucose, a Megazymes D-glucose assay kit (GOPOD FORMAT, K-GLUC, Megazyme Inc., Bray, Ireland) was employed. A factor of 0.9 was multiplied to convert the amount of glucose into starch, expressing the results in $\mathrm{g}$ of digested starch per $100 \mathrm{~g}$ of total starch on a dry basis. The experimental data were then fitted into a first-order equation to estimate the kinetics of starch hydrolysis:

$$
C_{t}=C_{\infty}\left(1-e^{-k t}\right)
$$

where $C_{t}, C_{\infty}$, and $k$ represent the hydrolyzed starch \% at time $t$, the maximum degree of starch hydrolysis in \% (at the infinite time), and the hydrolysis rate constant, respectively. 
2.10.2. Determination of protein hydrolysis. Prior quantification of free amino groups $\left(\mathrm{NH}_{2}\right)$, non-digested samples were hydrolyzed with $6 \mathrm{M} \mathrm{HCl}$, incubated at $110{ }^{\circ} \mathrm{C}$ for $24 \mathrm{~h}$. After this, the free amino groups in both digested (TCA) samples and non-digested samples were estimated by ortho-phthalaldehyde (OPA) method. ${ }^{30}$ The degree of hydrolysis (DH) was calculated based on the following equation:

$$
\mathrm{DH}(\%)=\frac{\mathrm{NH}_{2(\mathrm{DS})}-\mathrm{NH}_{2(t=0)}}{\mathrm{NH}_{2(\text { Total })}-\mathrm{NH}_{2(t=0)}} \times 100
$$

where: $\mathrm{NH}_{2}$ (DS) = free amino groups from digested sampleNH $(t=0)=$ free amino groups from samples at time 0 of digestionNH $\mathrm{N}_{2}($ total $)=$ maximum amount of $\mathrm{NH}_{2}$ present in the sample.

\subsection{Confocal laser scanning microscopy}

Zeiss 510 inverted microscope (Carl Zeiss microscopy, Oberkochen, Germany) was used to visualize the endosperm cell wall microstructure of raw and processed rice products destined for in vitro starch and protein hydrolysis. Flour particles $(425-250 \mu \mathrm{m})$ of raw rice and roasted rice products, and freshly prepared cooked rice particles (squeezed through $425 \mu \mathrm{m}$ ) were stained with $0.02 \%$ calcofluor-white dye and left to incubate for $10 \mathrm{~min}$. Samples were then excited at $405 \mathrm{~nm}$, and images were taken using a $40 \times$ (N.A. 1.3 oil immersion) objective lens.

\subsection{Statistical analysis}

One-way ANOVA was performed on the data collected to determine the significance of the processing treatments and maturity level using SPSS (version 11.5, SPSS Inc., Chicago, USA).
Data were treated independently for each processing treatment, but they were pooled out together irrespective of processing treatments to evaluate maturity level effect. Post hoc comparisons between independent variables were conducted using Tukey's HSD tests at $p<0.05$. Two-way ANOVA was computed to assess interactions between soaking and roasting conditions of simulated pepeta processing technology, treating "roasting" as a fixed effect and "soaking" as a random effect. Pearson correlation was used to investigate the relationship between protein digestibility and heat-induced protein interactions. Data are presented as means \pm standard deviation of at least two replicates of an immature polished rice flour.

\section{Results and discussion}

\subsection{Impact of processing on DOM and proximate composition of immature rice-based products}

The DOM and proximate composition of immature rice-based products at different maturity stages, soaked or not and roasted at a different temperature, are shown in Table 1. As expected, moisture decreased with increased roasting temperature, where roasted products at $120^{\circ} \mathrm{C}$ had the lowest values in both 18 and 26 DAH maturity. Soaking before roasting significantly increased the final moisture content of roasted products; due to the high initial moisture level of soaked grains.

Roasting with and without soaking significant decreased (except for $18 \mathrm{DAH}$ ) the lipid content of immature rice products, raw rice and pepeta showed higher values compared to roasted products in both maturity levels. This could be due to the observed low DOM, indicating a substantial amount of

Table 1 DOM and proximate analysis of TXD306 rice at different maturity levels and roasting conditions

Nutritional component (g per $100 \mathrm{~g}$, dwb)

\begin{tabular}{|c|c|c|c|c|c|c|}
\hline \multirow[b]{2}{*}{ Treatment } & \multirow[b]{2}{*}{ DOM (g per $100 \mathrm{~g}, \mathrm{dwb}$ ) } & \multirow[b]{2}{*}{ Moisture (g per $100 \mathrm{~g}$ ) } & & & & \\
\hline & & & Total lipid & Total protein $\#$ & Total ash & Total carbohydrates \\
\hline \multicolumn{7}{|l|}{18 DAH } \\
\hline $80-\mathrm{NS}^{a}$ & $0.28 \pm 0.04^{\mathrm{a}}$ & $19.11 \pm 1.80^{\mathrm{d}}$ & $0.62 \pm 0.02^{\mathrm{a}}$ & $9.01 \pm 0.16^{\mathrm{c}}$ & $1.15 \pm 0.41^{\mathrm{a}}$ & $89.22 \pm 0.17^{\mathrm{a}}$ \\
\hline $80-S$ & $0.41 \pm 0.03^{\mathrm{ab}}$ & $20.01 \pm 0.28^{\mathrm{d}}$ & $0.58 \pm 0.06^{\mathrm{a}}$ & $8.50 \pm 0.52^{b c}$ & $1.09 \pm 0.09^{\mathrm{a}}$ & $89.84 \pm 0.51^{\mathrm{ab}}$ \\
\hline $100-\mathrm{NS}$ & $0.65 \pm 0.03^{\mathrm{b}}$ & $15.09 \pm 0.13^{c}$ & $0.70 \pm 0.27^{\mathrm{a}}$ & $8.71 \pm 0.36^{\mathrm{c}}$ & $1.11 \pm 0.10^{\mathrm{a}}$ & $89.49 \pm 0.56^{\mathrm{ab}}$ \\
\hline $100-\mathrm{S}$ & $0.64 \pm 0.10^{\mathrm{b}}$ & $15.74 \pm 0.29^{c}$ & $0.65 \pm 0.06^{\mathrm{a}}$ & $7.98 \pm 0.04^{\mathrm{b}}$ & $1.12 \pm 0.09^{\mathrm{a}}$ & $90.26 \pm 0.04^{\mathrm{ab}}$ \\
\hline $120-\mathrm{NS}$ & $0.32 \pm 0.07^{\mathrm{a}}$ & $10.11 \pm 0.36^{\mathrm{a}}$ & $0.53 \pm 0.07^{\mathrm{a}}$ & $8.48 \pm 0.03^{b c}$ & $0.76 \pm 0.65^{\mathrm{a}}$ & $90.23 \pm 0.67^{\mathrm{ab}}$ \\
\hline $120-\mathrm{S}$ & $0.46 \pm 0.09^{\mathrm{ab}}$ & $12.32 \pm 0.18^{\mathrm{b}}$ & $0.55 \pm 0.02^{\mathrm{a}}$ & $7.86 \pm 0.13^{\mathrm{ab}}$ & $1.08 \pm 0.10^{\mathrm{a}}$ & $90.50 \pm 0.22^{\mathrm{b}}$ \\
\hline Pepeta & $1.23 \pm 0.04^{\mathrm{d}}$ & $10.80 \pm 0.46^{\mathrm{ab}}$ & $1.68 \pm 0.04^{\mathrm{b}}$ & $7.44 \pm 0.24^{\mathrm{a}}$ & $1.34 \pm 0.16^{\mathrm{a}}$ & $89.54 \pm 0.43^{\mathrm{ab}}$ \\
\hline Raw rice & $0.99 \pm 0.08^{c}$ & $11.33 \pm 0.26^{\mathrm{ab}}$ & $1.57 \pm 0.08^{b}$ & $7.90 \pm 0.10^{\mathrm{b}}$ & $1.23 \pm 0.15^{\mathrm{a}}$ & $89.30 \pm 0.23^{\mathrm{a}}$ \\
\hline \multicolumn{7}{|l|}{26 DAH } \\
\hline $80-\mathrm{NS}$ & $0.68 \pm 0.01^{\mathrm{bc}}$ & $16.18 \pm 0.10^{\mathrm{f}}$ & $1.48 \pm 0.65^{\mathrm{d}}$ & $7.91 \pm 0.33^{\mathrm{d}}$ & $1.08 \pm 0.09^{\mathrm{a}}$ & $89.53 \pm 0.92^{\mathrm{a}}$ \\
\hline $80-\mathrm{S}$ & $0.70 \pm 0.01^{b c}$ & $17.20 \pm 0.19^{\mathrm{g}}$ & $0.89 \pm 0.09^{b}$ & $7.78 \pm 0.09^{\mathrm{cd}}$ & $1.04 \pm 0.08^{\mathrm{a}}$ & $90.30 \pm 0.12^{\mathrm{ab}}$ \\
\hline $100-\mathrm{NS}$ & $0.48 \pm 0.05^{\mathrm{ab}}$ & $13.64 \pm 0.26^{\mathrm{d}}$ & $0.52 \pm 0.05^{\mathrm{a}}$ & $7.85 \pm 0.09^{\mathrm{cd}}$ & $1.03 \pm 0.07^{\mathrm{a}}$ & $90.61 \pm 0.06^{\mathrm{ab}}$ \\
\hline $100-\mathrm{S}$ & $0.77 \pm 0.03^{c}$ & $14.33 \pm 0.17^{\mathrm{e}}$ & $1.38 \pm 0.29^{\mathrm{bd}}$ & $7.77 \pm 0.23^{\mathrm{cd}}$ & $1.05 \pm 0.13^{\mathrm{a}}$ & $89.79 \pm 0.34^{\mathrm{a}}$ \\
\hline $120-\mathrm{NS}$ & $0.40 \pm 0.07^{\mathrm{a}}$ & $10.45 \pm 0.19^{\mathrm{a}}$ & $1.04 \pm 0.03^{b c}$ & $7.10 \pm 0.27^{\mathrm{ab}}$ & $1.25 \pm 0.10^{\mathrm{a}}$ & $90.61 \pm 0.18^{\mathrm{ab}}$ \\
\hline $120-\mathrm{S}$ & $0.52 \pm 0.06^{\mathrm{ab}}$ & $11.65 \pm 0.23^{c}$ & $0.58 \pm 0.03^{\mathrm{a}}$ & $6.98 \pm 0.06^{\mathrm{ab}}$ & $0.99 \pm 0.06^{\mathrm{a}}$ & $91.46 \pm 0.14^{\mathrm{b}}$ \\
\hline Pepeta & $1.37 \pm 0.06^{\mathrm{e}}$ & $10.08 \pm 0.19^{\mathrm{a}}$ & $1.85 \pm 0.12^{\mathrm{d}}$ & $7.16 \pm 0.01^{\mathrm{b}}$ & $1.44 \pm 0.51^{\mathrm{a}}$ & $89.56 \pm 0.53^{\mathrm{a}}$ \\
\hline Raw rice & $1.15 \pm 0.19^{\mathrm{d}}$ & $11.15 \pm 0.04^{\mathrm{b}}$ & $1.63 \pm 0.07^{\mathrm{cd}}$ & $7.36 \pm 0.11^{b c}$ & $1.27 \pm 0.19^{\mathrm{a}}$ & $89.75 \pm 0.34^{\mathrm{a}}$ \\
\hline
\end{tabular}

${ }^{a} 80,100$ and 120 are roasting temperatures $\left({ }^{\circ} \mathrm{C}\right)$, NS - not soaked, S - soaked in cold water for $12 \mathrm{~h}$ before roasting, DAH - days after $50 \%$ heading, dwb - dry weight basis, DOM - degree of milling by surface lipid content. For each maturity level, values in each column with different superscripted letters are statistically different $(p \leq 0.05)$. " Significance difference between maturity levels $(p \leq 0.05)$. Data expressed as mean \pm standard deviation of three replicates. 
bran residual on the surface of raw rice and pepeta compared to other products (Table 1). In this study, DOM refers to the quantity of bran and polish removed from brown rice during milling operations. ${ }^{19}$ Thus high amount of bran residual (less DOM) could be associated with increase in the total lipids content of raw and pepeta samples as rice brans contain $20 \%$ lipids. ${ }^{31}$ Roasting at $80{ }^{\circ} \mathrm{C}$ significantly enhanced the protein content of raw rice, but slightly decreased as the roasting temperature increased. This suggests that proteins are not yet concentrated on the surface of the endosperm in immature grains used in this study. Less DOM (higher amount of bran fraction/surface lipid content) in heavily roasted grains diluted the endosperm, so less amount of $\mathrm{N}$ measured by Dumas. Proteomic studies ${ }^{32-34}$ revealed metabolic changes of rice grain during reserve accumulations; variations among grains at 7, 10 and 14 days after flowering (DAF) were much higher compared at 28 and $42 \mathrm{DAF}^{35}$ Besides, rice proteins are solely produced in the starchy endosperm. ${ }^{36}$ However, they accumulate on the outer surface of the endosperm as rice grains develop to optimum maturity. ${ }^{37}$ Though soaking before roasting had no significant effect (except at $100{ }^{\circ} \mathrm{C}, 18 \mathrm{DAH}$ ) on protein content, slightly low values were observed in roasted products after soaking, indicating a more severe heat denaturation or aggregation in soaked products (section 3.4). Total carbohydrate slightly increases with the roasting temperatures. This could be associated with the decrease in protein content which is the second in abundant after starch in the polished rice, as carbohydrates content was determined by the subtraction method (section 2.3). Maturity level had a significant effect on lipid, protein and carbohydrate contents; high values were observed at $18 \mathrm{DAH}$ compared to $26 \mathrm{DAH}$ for protein content. The opposite was observed for lipids and carbohydrate contents. The decrease in protein content and increase in carbohydrate content could be related to the accumulation of starch during rice grain development. ${ }^{8,38}$ An interaction between soaking and roasting temperature was significant in DOM, total lipid and total carbohydrate at $26 \mathrm{DAH}$.

Consumption of dietary fiber is associated with reduced risk for cardiovascular disease, diabetes and colorectal cancer. ${ }^{39,40}$ Table 2 reports the results of dietary fiber content for the two maturity levels. In all samples (raw rice, pepeta and roasted products), very low SDF content was observed compared to IDF in the corresponding samples, in line with previous paper. ${ }^{11}$ Roasting significantly affects SDF content, with pepeta showing the highest values possibly due to the lower DOM. Though no significant changes were observed among roasted products, the SDF/TDF ratio increased with roasting temperatures (Table 2), indicating possible conversion of insoluble fiber to soluble fiber during heat processing. ${ }^{41}$ Intake of SDF increases viscosity in the digestive tract whereby prolong gastric emptying, reduce rate of starch digestion and glucose absorption, and associated to increased satiety and reduced postprandial blood glucose level. ${ }^{41-43}$ On the contrary, IDF and TDF varied significantly (except in $26 \mathrm{DAH}$ at $100{ }^{\circ} \mathrm{C}$ ) at $120{ }^{\circ} \mathrm{C}$, decreasing as roasting temperature increases. These results agree with Naumann et al., ${ }^{41}$ who reported TDF degradation in extruded lupin kernels as a function of temperature when processed at 25,100 and $150^{\circ} \mathrm{C}$. In that study, high heat treatment (at $120^{\circ} \mathrm{C}$ ) may have caused glycosidic bonds cleavage, converting insoluble polysaccharides to smaller

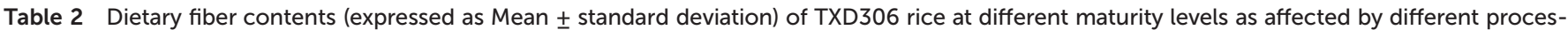
sing conditions

Dietary fiber (g per $100 \mathrm{~g}$ )

\begin{tabular}{|c|c|c|c|c|}
\hline \multirow[b]{2}{*}{ Treatment } & & \multirow[b]{2}{*}{$\mathrm{SDF} / \mathrm{TDF}^{*}(\%)$} \\
\hline & SDF & $\mathrm{IDF}^{*}$ & TDF & \\
\hline \multicolumn{5}{|l|}{18 DAH } \\
\hline $80-\mathrm{NS}$ & $0.55 \pm 0.01^{\mathrm{b}}$ & $5.12 \pm 0.17^{\mathrm{c}}$ & $5.68 \pm 0.19^{\mathrm{b}}$ & $9.743 \pm 0.12^{\mathrm{ab}}$ \\
\hline $80-\mathrm{S}$ & $0.59 \pm 0.11^{\mathrm{b}}$ & $4.97 \pm 0.45^{c}$ & $5.56 \pm 0.33^{\mathrm{b}}$ & $10.67 \pm 2.68^{\mathrm{ab}}$ \\
\hline $100-\mathrm{NS}$ & $0.60 \pm 0.03^{b}$ & $4.74 \pm 0.64^{\mathrm{bc}}$ & $5.34 \pm 0.60^{\mathrm{b}}$ & $11.38 \pm 1.94^{\mathrm{ab}}$ \\
\hline $100-S$ & $0.59 \pm 0.06^{\mathrm{b}}$ & $5.01 \pm 0.75^{\mathrm{c}}$ & $5.61 \pm 0.69^{b}$ & $10.75 \pm 2.38^{\mathrm{ab}}$ \\
\hline $120-\mathrm{NS}$ & $0.66 \pm 0.13^{b}$ & $2.41 \pm 0.78^{\mathrm{a}}$ & $3.08 \pm 0.65^{\mathrm{a}}$ & $22.49 \pm 4.90^{\mathrm{b}}$ \\
\hline $120-\mathrm{S}$ & $0.63 \pm 0.08^{b}$ & $2.68 \pm 0.70^{\mathrm{a}}$ & $3.31 \pm 0.78^{\mathrm{a}}$ & $19.22 \pm 2.17^{\mathrm{ab}}$ \\
\hline Pepeta & $1.02 \pm 0.09^{c}$ & $4.52 \pm 0.01^{\mathrm{abc}}$ & $5.54 \pm 0.10^{\mathrm{b}}$ & $18.48 \pm 1.24^{\mathrm{ab}}$ \\
\hline Raw & $0.39 \pm 0.03^{\mathrm{a}}$ & $4.66 \pm 0.31^{b c}$ & $5.05 \pm 0.28^{\mathrm{ab}}$ & $7.826 \pm 1.08^{\mathrm{a}}$ \\
\hline \multicolumn{5}{|l|}{26 DAH } \\
\hline $80-\mathrm{NS}$ & $0.70 \pm 0.07^{\mathrm{b}}$ & $3.97 \pm 0.02^{b c}$ & $4.67 \pm 0.05^{\mathrm{bcd}}$ & $14.97 \pm 1.39^{b c}$ \\
\hline $80-\mathrm{S}$ & $0.67 \pm 0.01^{\mathrm{b}}$ & $4.48 \pm 0.46^{\mathrm{c}}$ & $5.14 \pm 0.48^{\mathrm{d}}$ & $13.01 \pm 0.95^{\mathrm{ab}}$ \\
\hline $100-\mathrm{NS}$ & $0.72 \pm 0.02^{\mathrm{bc}}$ & $2.62 \pm 0.07^{\mathrm{a}}$ & $3.47 \pm 0.11^{\mathrm{ab}}$ & $21.68 \pm 0.04^{\mathrm{d}}$ \\
\hline $100-S$ & $0.71 \pm 0.01^{\mathrm{bc}}$ & $3.66 \pm 0.12^{\mathrm{abc}}$ & $4.37 \pm 0.10^{\mathrm{abcd}}$ & $16.29 \pm 0.54^{b c}$ \\
\hline $120-\mathrm{NS}$ & $0.86 \pm 0.06^{b c}$ & $2.61 \pm 0.05^{\mathrm{a}}$ & $3.34 \pm 0.09^{\mathrm{a}}$ & $24.75 \pm 0.91^{\mathrm{d}}$ \\
\hline $120-\mathrm{S}$ & $0.86 \pm 0.09^{b c}$ & $2.81 \pm 0.19^{\mathrm{ab}}$ & $3.67 \pm 0.28^{\mathrm{abc}}$ & $23.40 \pm 0.74^{d}$ \\
\hline Pepeta & $0.94 \pm 0.10^{c}$ & $3.80 \pm 0.34^{b c}$ & $4.75 \pm 0.24^{\mathrm{cd}}$ & $19.94 \pm 3.12^{\mathrm{cd}}$ \\
\hline Raw & $0.44 \pm 0.02^{\mathrm{a}}$ & $4.48 \pm 0.57^{c}$ & $4.93 \pm 0.59^{\mathrm{d}}$ & $9.049 \pm 0.67^{\mathrm{a}}$ \\
\hline
\end{tabular}

DAH - days after 50\% heading, SDF - soluble dietary fiber, IDF - insoluble dietary fiber, TDF - total dietary fiber. 80,100 and 120 indicate rice roasted at the corresponding temperatures $\left({ }^{\circ} \mathrm{C}\right)$, NS - not soaked, $\mathrm{S}$ - water-soaked rice at room temperature for $12 \mathrm{~h}$ prior roasting, pepeta locally prepared rice flakes, raw - unprocessed rice. For each maturity level, labels with different letters indicate a statistically significant difference in fiber content $(p \leq 0.05)$ for each dietary fiber parameter. ${ }^{*}$ Significance difference between maturity levels $(p \leq 0.05)$. 
fractions, ${ }^{39,44}$ which are too small to be detected as dietary fiber due to low molecular weight. ${ }^{45}$ It is worth noting that the retained residuals upon filtration $(40-60 \mu \mathrm{m})$ of samples mixture after a series of incubation (section 2.5) were considered a dietary fiber. The IDF consumption increase bulk volume and decrease transit time associated with the increased dietary fiber supply, result in increased satiety and decreased saturated fat intake. ${ }^{41,42}$ Soaked roasted products showed slightly lower values of SDF and higher values of IDF and TDF (except at $80{ }^{\circ} \mathrm{C}$ for $18 \mathrm{DAH}$ ) than unsoaked products for both maturity levels. Some energy could be used to evaporate extra water in soaked paddy grains during roasting, associated with reduction in dietary fiber degradation and conversion of IDF to SDF. No significant difference in IDF and TDF content were observed between pepeta and raw rice, possibly due to high bran residual observed in both samples as DOM (Table 1). Rice bran is rich in dietary fiber (27.6-33.3\%) in which about $90 \%$ of the content is IDF. ${ }^{46}$ IDF and SDF/TDF ratio differed significantly between maturity levels, with higher values observed at 18 and $26 \mathrm{DAH}$, respectively, suggesting increase in conversation of IDF to SDF when immature rice grain developed from 18 to $26 \mathrm{DAH}$. This increase could be associated with the impact of roasting temperature on dietary fiber, being prominent at $26 \mathrm{DAH}$ due to less initial moisture content of immature grains compared to $18 \mathrm{DAH}$. Except for SDF and TDF at $26 \mathrm{DAH}$, no interaction effect was found between soaking and roasting.

\subsection{Effect of heat processing on selected vitamins and minerals}

Fig. 2 (panels a-h) present the content in selected vitamin Bs of processed rice products at 18 and 26 DAH maturity. Rice processing significantly affected the final concentration of thiamine, riboflavin, nicotinic acid and nicotinamide content; pepeta showed the highest values except for nicotinic acid at $18 \mathrm{DAH}$ (Fig. 2 panel e) and nicotinamide at $26 \mathrm{DAH}$ (Fig. 2 panel $\mathrm{h}$ ). This is likely due to high bran residuals remaining on the surface of pepeta grains after pounding (Table 1) as vitamins concentrate in brans. ${ }^{47,48}$ Vitamin Bs content varied significantly among roasted samples as well. Though no significant change was observed in $18 \mathrm{DAH}$, the thiamine content in both maturity levels (Fig. 2 panels a and b) decreased as roasting temperature increase for both roasting with and without soaking, probably due to thermal breakdown. The results are contrary to a previous study ${ }^{49}$ which reported thiamine content to increase with the severity of heat treatment (during soaking and steaming). This discrepancy could be due to different employed parboiling regimes; warm soaking and steaming (wet-heating treatment) in their study vs. cold soaking and roasting (dry-heat treatment) in our study. Fig. 2 (panels $\mathrm{c}-\mathrm{h}$ ) further indicates that riboflavin, nicotinic acid and nicotinamide contents increased with roasting temperature. Samples roasted after soaking showed slightly high value compared to those roasted without soaking. Since the content in these vitamins does not correlate to DOM, it is possible that some inward diffusion of nutrients from bran layer to endo- sperm had occurred during soaking ${ }^{50,51}$ and roasting. Upon roasting of immature (both soaked and unsoaked) paddy grains, the starch granule in the endosperm expanded and swelled by absorbing the available free water molecule as it gelatinizes. ${ }^{50}$ The onset of starch gelatinization created a moisture gradient between the bran layer and starchy endosperm caused inward diffusion of free water molecules and water-soluble vitamins from the bran layer into starchy endosperm to facilitate further the gelatinization process. ${ }^{52,53}$ It is important to note that the initial moisture content of fresh immature rice grain, below $28 \mathrm{DAH}$ (day after 50\% heading), was sufficient to fully gelatinize starch during pepeta processing. ${ }^{7}$ Maturity level had a significant effect on riboflavin, nicotinic acid and nicotinamide contents; high values were observed at $26 \mathrm{DAH}$ compared to $18 \mathrm{DAH}$ for riboflavin content, whereas the opposite was observed for nicotinic acid and nicotinamide content. A study by $\mathrm{Ji}$ et $a l^{8}$ reported decreases in vitamins B contents, including riboflavin and/or their conjugates, during maturation of two Korean rice varieties, possibly due to their biochemical function as cofactors and precursors in regulating plant metabolism. ${ }^{54-56}$ No interaction effect was found between soaking and roasting in all assessed vitamin Bs content.

Fig. 3 indicates significant changes in iron (Fig. 3 panels a and $\mathrm{b}$ ) and zinc (Fig. 3 panels c and d) when rice processed under different conditions; the lowest iron content values were observed in raw rice. Among roasted products, the iron content significantly increased as roasting temperature increase; soaked products showed substantial-high values compared to roasted unsoaked products. The increase of minerals after roasting could be due to inward diffusion into endosperm during the soaking process ${ }^{51}$ and fixation of micronutrients on the surface of the rice grain endosperm during the gelatinization process ${ }^{57}$ for unsoaked rice products. On the contrary, roasting slightly reduced zinc content in roasted products, soaking before roasting showed an inconsistent trend. The results agree with the previous study, ${ }^{58,59}$ which reported a contrasting heat treatment effect on iron and zinc; iron is highly affected compared to zinc upon heat treatment. This could be attributed to differential interactions between iron and zinc with the food matrix, ${ }^{60-63}$ which has produced different inwards diffusion so that after removing different amount of bran (dehulling and polishing) it resulted in different amount of minerals accumulated in the endosperm. Though the maturity level had no significant effect, an interaction effect was found between soaking and roasting for iron and zinc at $18 \mathrm{DAH}$.

\subsection{Starch characteristics of processed rice products}

Table 3 shows the starch properties of processed rice products at different maturity and under different processing conditions. The starch content, including the amount of RS, is mainly unaffected by roasting temperature and soaking, and comparable to the levels measured in locally prepared pepeta. Health benefit of RS intake as part of dietary fiber, include its contribution to gastrointestinal health, as a source of ben- 

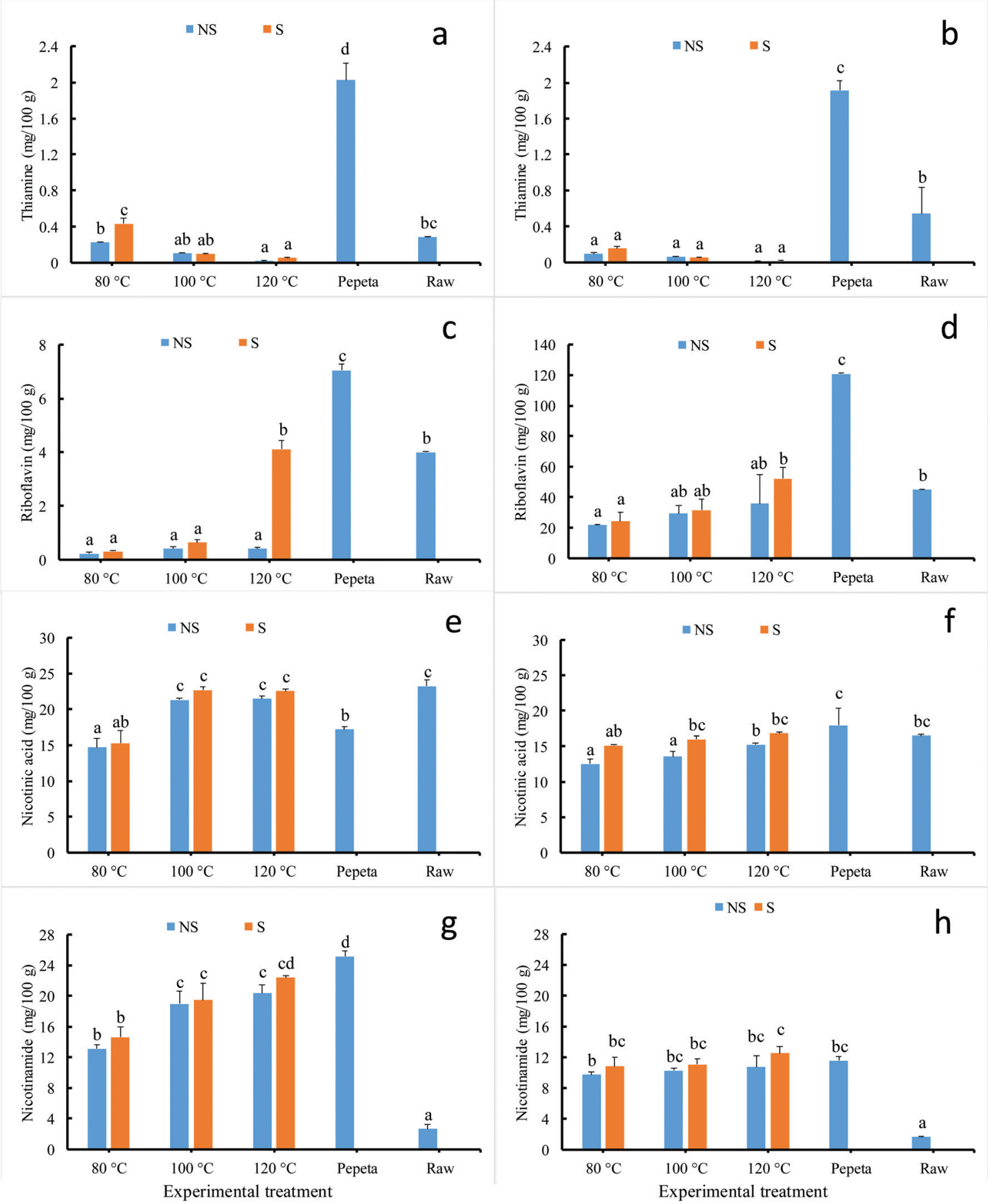

Fig. 2 Effect of processing condition on vitamin Bs content of TXD306 rice (in dry weight basis) at 18 DAH (days after 50\% heading) (a, C, e and g) and $26 \mathrm{DAH}\left(\mathrm{b}, \mathrm{d}, \mathrm{f}\right.$ and $\mathrm{h}$ ) maturity levels. 80,100 and $120^{\circ} \mathrm{C}$ indicate rice roasted at the corresponding temperatures, pepeta - locally prepared rice flakes, raw - unprocessed rice, NS - not soaked, $\mathrm{S}$ - water-soaked rice at room temperature for $12 \mathrm{~h}$ prior roasting. Labels with different letters indicate a statistically significant difference in vitamin Bs content $(p \leq 0.05)$. Each bar chart represents mean and standard deviation of two replicates.

eficial microbial fermentation in the large intestine, further associated with reduction in the glycaemic response. ${ }^{64}$ However, the samples produced in the laboratory have a lower RS than raw rice, which suggests a very limited retrogradation when stored for 4 weeks before analysis. Rice cooking slightly decreased the amylose content compared to raw rice possibly due to amylose leaching into water during cooking. ${ }^{65,66}$ It should be noted that rice was cooked in excess boiling water until fully gelatinized (section 2.2). Contrary to cooking (wet heat), roasting (dry heat) enhanced the amylose content; roasted products showed higher amylose content than raw rice. The results agree with a previous study, ${ }^{28}$ which reported 

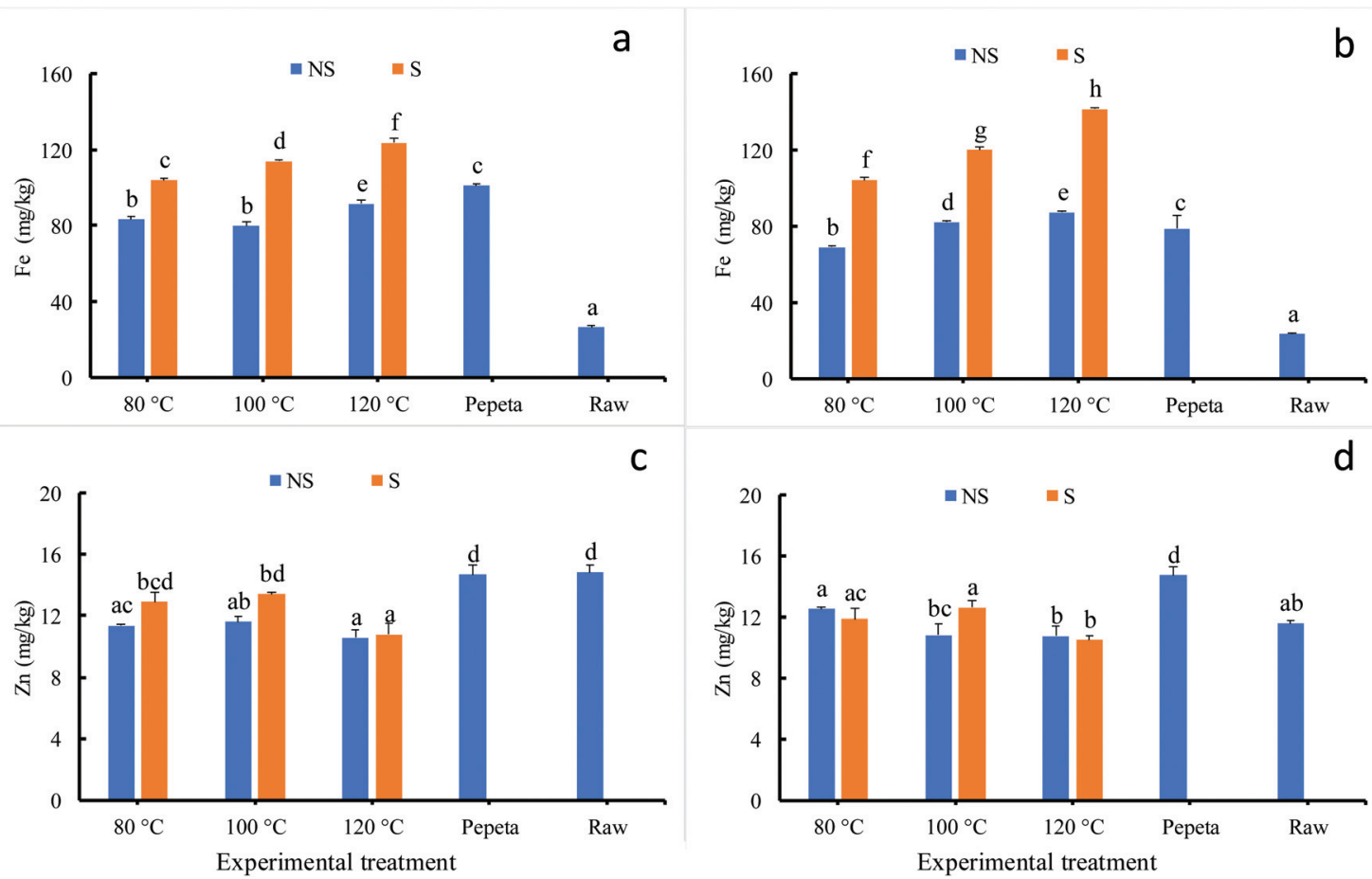

Fig. 3 Fe and Zn contents (in dry weight basis) of TXD306 rice at 18 DAH (days after $50 \%$ heading) (a and c) and 26 DAH (b and d) maturity levels as function of different processing conditions. 80,100 and $120^{\circ} \mathrm{C}$ indicate rice roasted at the corresponding temperatures, pepeta - locally prepared rice flakes, raw - unprocessed rice, NS - not soaked, S - water-soaked rice at room temperature for $12 \mathrm{~h}$ prior roasting. Labels with different letters indicate a statistically significant difference in Fe and $\mathrm{Zn}$ content $(p \leq 0.05)$. Each bar chart represents mean and standard deviation of two replicates.

Table 3 Starch properties of TXD306 variety at different maturity and roasting conditions

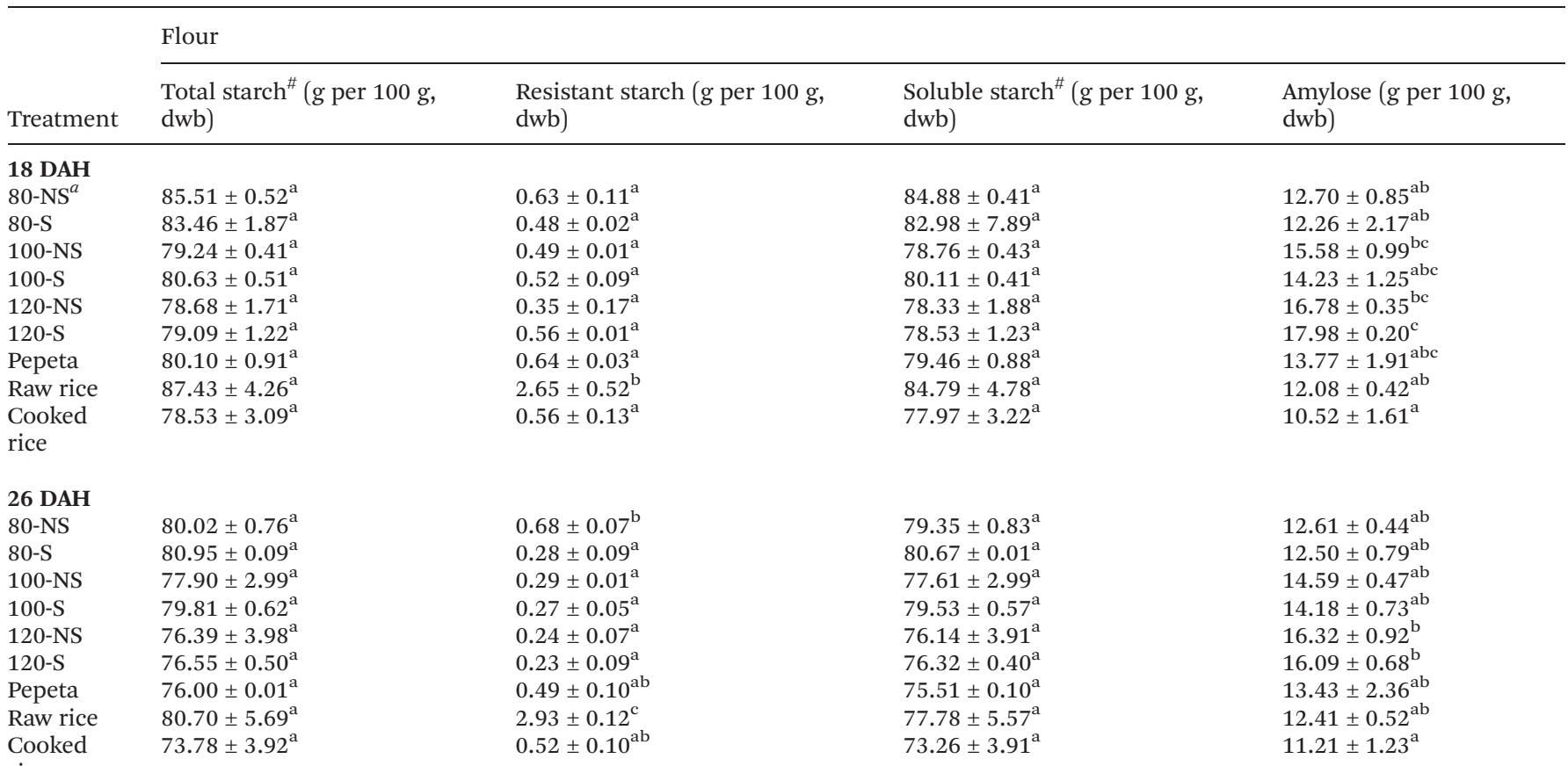

rice

${ }^{a} 80,100$ and 120 are roasting temperatures $\left({ }^{\circ} \mathrm{C}\right)$, NS - not soaked, S - soaked in cold water for $12 \mathrm{~h}$ before roasting, DAH - days after $50 \%$ heading, dwb - dry weight basis. Values in each column with different superscripted letters are statistically different $(p \leq 0.05)$ for each maturity. ${ }^{\#}$ Significance difference between maturity levels $(p \leq 0.05)$. Data expressed as mean \pm standard deviation of three replicates. 
higher apparent amylose content in heat-moisture treated starch than native starch in the rice. Though no significant effect observed among roasted samples (except for $18 \mathrm{DAH}$ at $120^{\circ} \mathrm{C}$ ), the amylose content increased with roasting temperature in both flour and starch samples. These results can be explained by increased susceptibility towards hydrolysis by enzymes (fungal $\alpha$-amylase and amyloglucosidase) on heattreated samples due to more gelatinized starch, increasing the quantification of amylose by the enzymatic method used. Alternatively, it has been proposed that the level of apparent amylose can increase after heat moisture treatment because of the formation of the amylose-amylopectin complex upon heating. ${ }^{28}$ This would limit the precipitation of amylopectin by concanavalin A, therefore, increasing the apparent amount of amylose. However, slightly lower values (except at $120{ }^{\circ} \mathrm{C}, 18$ $\mathrm{DAH})$ were observed in roasted products with soaking compared to roasted products without soaking, possibly due to amylose leaching into soaking water during the soaking process. ${ }^{65,66}$ It is worth noting that the leaching out of amylose from paddy grains into soaking water is less pronounced compare to that during cooking of polished rice due to husk and bran barrier layers ${ }^{67}$ and the fact the amylose is more tightly associated to amylopectin in native starch granules. The starch properties did not vary significantly between maturity levels except for starch content (TS and SS), high values observed at $18 \mathrm{DAH}$ compared to $26 \mathrm{DAH}$. Similar results were found in our previous study on nutritional characterization of immature TXD306 and Lawama rice grains, reported decrease of starch content as rice grains developed from dough grain stage (DGS, 15-21 DAH) to mature grain stage (MGS, 22-28 $\mathrm{DAH}){ }^{7}$ No interaction effect was found between soaking and roasting except RS for flour samples at $26 \mathrm{DAH}$.

\subsection{Microstructure properties of processed rice products}

To visualize the structure of the endosperm cells of the rice samples, confocal laser scanning microscopy (CLSM) was used (Fig. 4 panels a-i). An intact cell wall structure (staining of the cell walls with light blue) was observed in raw rice flour
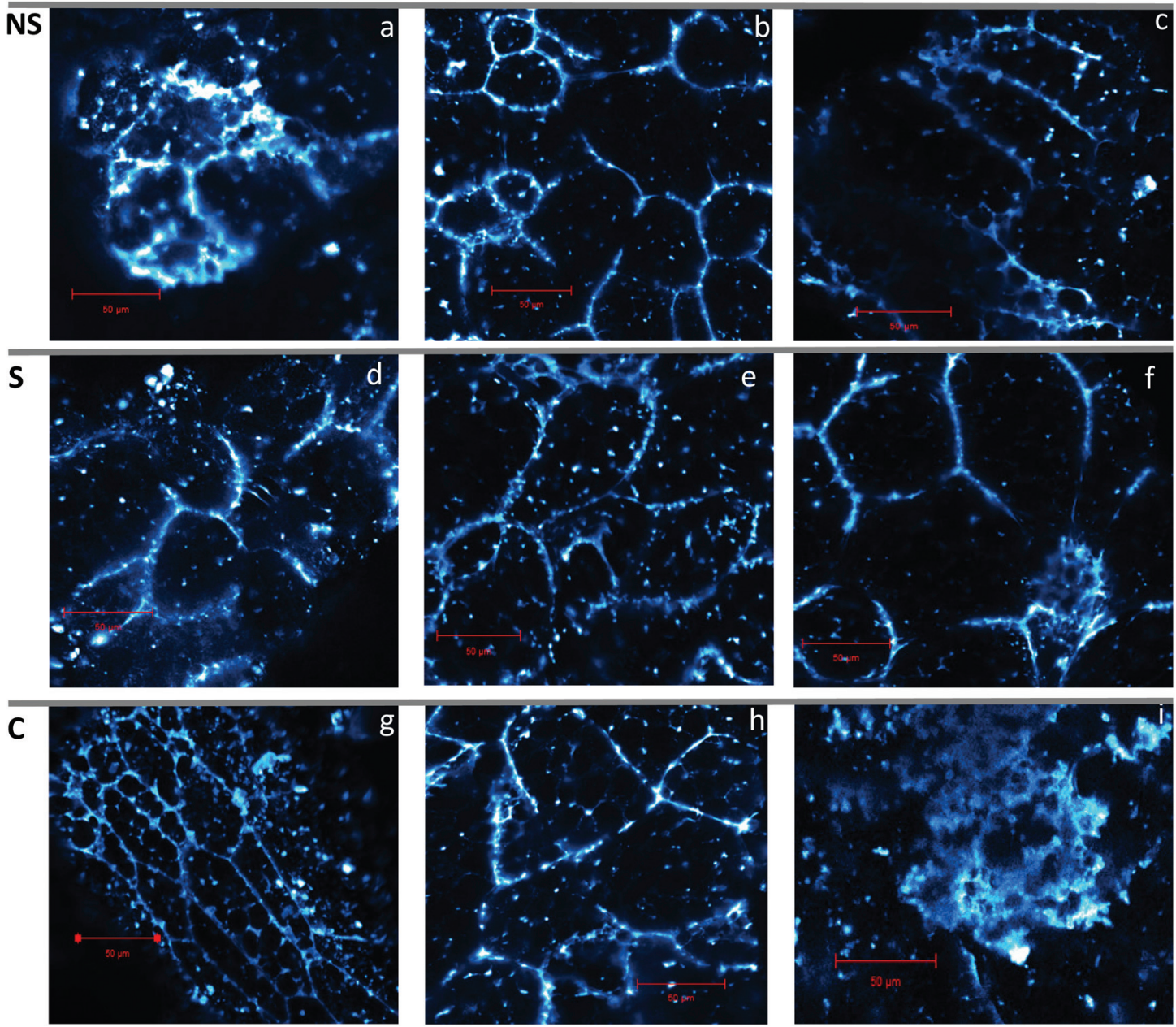

Fig. 4 Confocal images showing cell walls of rice flour particle $(425-250 \mu \mathrm{m})$ for roasted rice at $80^{\circ} \mathrm{C}\left(\mathrm{a}\right.$ and d), $100{ }^{\circ} \mathrm{C}$ (b and e), and $120{ }^{\circ} \mathrm{C}$ ( $\mathrm{C}$ and $\mathrm{f})$, raw rice (g), pepeta (h) and cooked rice (i) squeezed through $425 \mu \mathrm{m}$ sieve. NS - not soaked (a-c), S - water-soaked rice at room temperature for $12 \mathrm{~h}$ prior roasting $(\mathrm{d}-\mathrm{f}), \mathrm{C}-$ control samples $(\mathrm{g}-\mathrm{i})$. Cell walls were stained in light blue. Micrographs were taken using $40 \times$ objective lens. Scale bar is $50 \mu \mathrm{m}$. 
samples (Fig. 4 panel g), which was used as a reference sample for native structure in this study. This resembles previous findings in raw rice flour. ${ }^{7}$ Fig. 4 (panel h) shows partial disruption of the cell wall profile in pepeta, indicating possible mechanical damage due to the pounding and milling process. Cooked rice (Fig. 4 panel i) showed complete loss of endosperm cell wall structure, which was used as a reference sample for maximum disruption. This was expected because rice grains lose their structure when cooked in excess boiling water until fully gelatinized. ${ }^{7}$ Intact cell walls were observed in roasted samples (Fig. 4 panels a-f) even after mechanical milling of samples into flour particles $(425-250 \mu \mathrm{m})$, with no noticeable differences in cell wall integrity among different roasting temperature, and between soaked and corresponding unsoaked samples. Change in endosperm cell walls profiles was observed in roasted samples compared to raw rice and related to increased cell volume with a decrease in elongation, possibly due to swelling and expansion of starch granules as it gelatinizes during roasting. ${ }^{50}$ Soaking before roasting did not affect cell volume compared to roasted samples due to a slight moisture gradient between initial moisture content (fresh unsoaked immature paddy, 33-41\%) and saturated moisture content (soaked immature paddy, 48-50\%) after cold water soaking, as the diffusion of water during soaking is governed by the moisture gradient between the surface of the grain and the center (starchy endosperm). ${ }^{53,68}$ It is worth noting that when rice samples were cooked in excess boiling water, they reached a moisture content up to $82 \%$, resulted in rapturing of the cell wall as the consequences of the starch gelatinization process due to excessive water absorption.

\subsection{Impact of rice processing on in vitro starch and protein digestibility}

3.5.1. Starch hydrolysis. Fig. 5 reports starch digestograms of the processed rice samples. The digestograms follow firstorder kinetic equation (except raw rice), like those reported in previous studies. ${ }^{7,28,69}$ All processed rice products exhibited a faster and higher extent of starch hydrolysis than raw rice (Fig. 5 panels a, b and e). However, soaking showed inconsistent trends (Fig. 5 panels c, d and f). The $C_{\infty}$ and $k$ values esti-

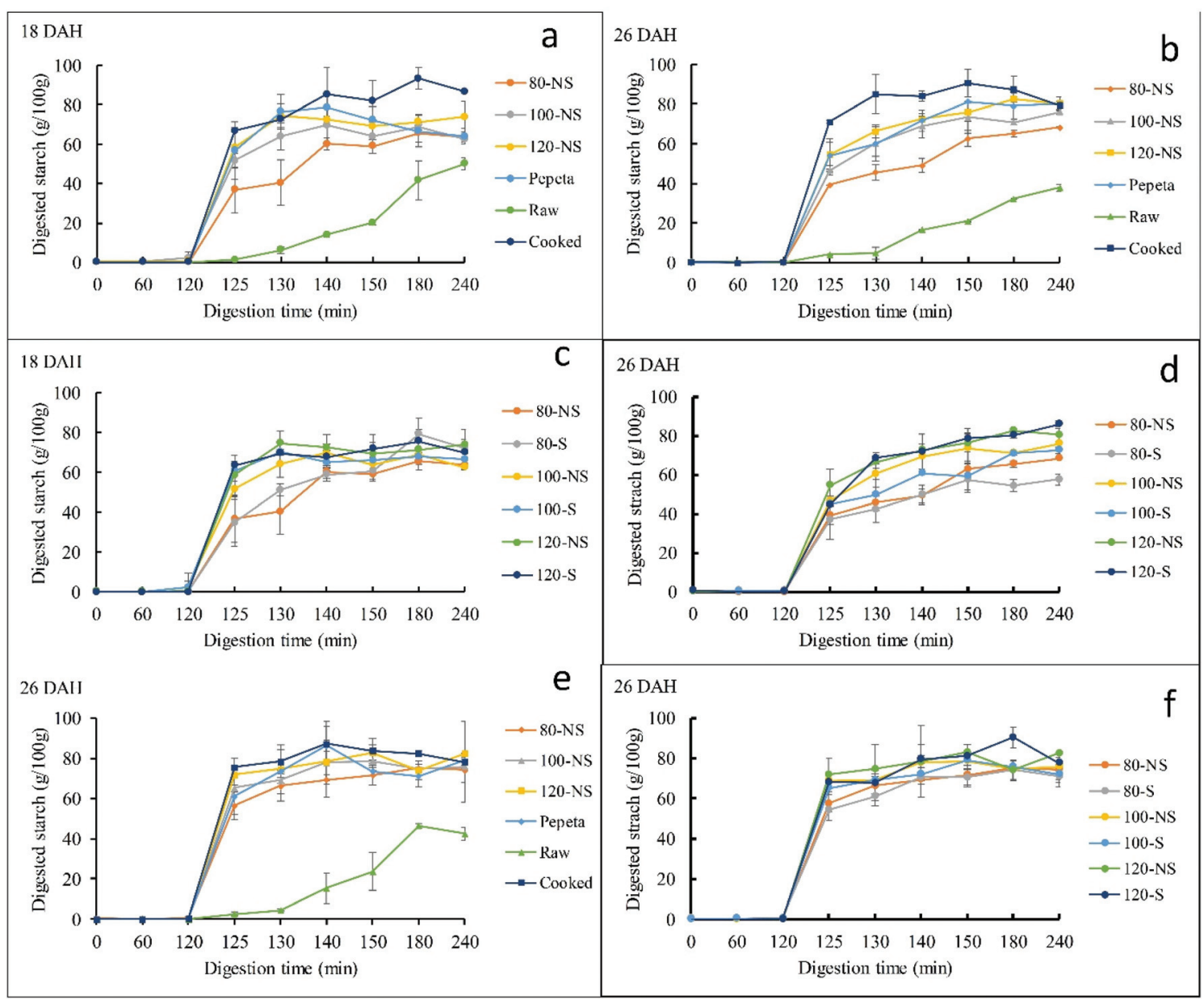

Fig. 5 Digestograms of starch enzymatic hydrolysis in vitro for TXD306 flour (a-d) and starch (e and f) samples as a function of processing conditions ( $a, b$ and e) and soaking prior roasting effect (c, d and f). 80, 100 and 120 are roasting temperatures $\left({ }^{\circ} \mathrm{C}\right.$ ), NS - not soaked, $\mathrm{S}-$ water-soaked rice at room temperature for $12 \mathrm{~h}$ prior roasting, pepeta - locally prepared rice flakes, raw - unprocessed rice, cooked - cooked rice, DAH - days after $50 \%$ heading (maturity level). Error bar represent standard deviation for means of two replicates. 
mated by fitting the experimental data to the first-order equation justifies the observed trend of the digestograms (Table 4 ). The $C_{\infty}$ and $k$ values differ significantly among rice products, raw rice showing the lowest values than processed rice products given the substantial amount of resistant starch type I and II. ${ }^{70,71}$ The starch digestibility in roasted samples (except $k$ value at $18 \mathrm{DAH}$ ) was lower than in cooked rice, possibly due to less damaged endosperm cell wall structure in roasted samples than cooked rice (section 3.4). Besides, aggregation of proteins (section 3.6), perhaps also favored by Maillard reaction, may have made starch granules more difficult to attack by amylase. Lower starch digestibility in dry heat parboiled rice compared to wet heat parboiled rice has been reported in a previous study, $^{72}$ indicate possible reduction of the glycemic index when consumed. Roasting conditions significantly affected $C_{\infty}$ and $k$ among roasted products, increasing as the roasting temperature increased. The results could be due to a lower extent of gelatinization at lower roasting temperatures. ${ }^{72,73}$ Though not significantly, soaking before roasting slight increased $C_{\infty}$ and $k$ values (except $k$ value at $80^{\circ} \mathrm{C}, 18 \mathrm{DAH}$ ) compared to roasting without soaking for $18 \mathrm{DAH}$, whereas no consistency trend was observed at 26 $\mathrm{DAH}$ for both flour and starch samples. Though the same trend in increasing starch digestibility as the roasting temperature increase was observed in isolated starch, the isolated starch samples had higher $C_{\infty}$ and $k$ (except $k$ value of raw rice at $26 \mathrm{DAH})$ compared to flour samples. This result suggests a differential effect on the starch rather than on cell walls is one reason for the lower digestibility at a lower temperature. The rate constant $(k)$ differed significantly between maturity levels, showing high values at $18 \mathrm{DAH}$ compared to $26 \mathrm{DAH}$. This contrast to the pervious study, suggested both $C_{\infty}$ and $k$ values of cooked rice were not influenced by maturity level. ${ }^{7}$ The discrepancy could be due to high extent of starch gelatinization in $18 \mathrm{DAH}$ samples during roasting as a result of high initial moisture content of paddy grains compared to $26 \mathrm{DAH}$, associated with an increased enzymatic starch digestibility. ${ }^{72,73}$ Except for $C_{\infty}$ for flour samples at $26 \mathrm{DAH}$, no interaction effect was observed between soaking and roasting.

3.5.2. Protein hydrolysis. Fig. 6 shows in vitro hydrolysis of protein in the different rice products. Only a limited protein hydrolysis was achieved after gastric digestion, as previously reported for other plant-food products. ${ }^{70,71}$ Rice processing significantly increased the protein hydrolysis; the lowest and the highest intestinal digestion values were observed in raw rice and cooked rice, respectively (Fig. 6 panels a and b, Table 4). The low protein digestibility of raw rice is due to intact cellular structure (section 3.4), which hinder proteolytic enzymes to easily interact with substrates. ${ }^{70,71}$ Dry roasting increases the digestibility of rice proteins, but protein digestibility in roasted samples is lower than that of cooked rice, contrary to what was reported in our previous work. ${ }^{7}$ This inconsistency could be due to different particle size of the flour samples between the two studies: pepeta samples were pounded and sieved through a $425 \mu \mathrm{m}$ sieve in the previous study. ${ }^{7}$ In this study, roasted samples (including pepeta) were

Table 4 Estimated invitro digestion parameters for starch and protein of TXD306 rice variety at different maturity and processing conditions

\begin{tabular}{|c|c|c|c|c|c|c|}
\hline \multirow[b]{2}{*}{ Treatment } & \multicolumn{2}{|c|}{ Starch digestion: flour } & \multicolumn{2}{|c|}{ Starch digestion: starch } & \multicolumn{2}{|l|}{ Protein digestion $^{b}$} \\
\hline & $\begin{array}{l}C_{\infty} \\
\text { (g per } 100 \mathrm{~g}, \mathrm{dwb})\end{array}$ & $k^{\$}\left(\min ^{-1}\right)$ & $\begin{array}{l}C_{\infty} \\
(\mathrm{g} \text { per } 100 \mathrm{~g}, \mathrm{dwb})\end{array}$ & $k\left(\min ^{-1}\right)$ & $\begin{array}{l}\text { Gastric } \\
\text { (g per } 100 \mathrm{~g}, \mathrm{dwb})\end{array}$ & $\begin{array}{l}\text { Intestinal } \\
\text { (g per } 100 \mathrm{~g}, \mathrm{dwb})\end{array}$ \\
\hline \multicolumn{7}{|l|}{18 DAH } \\
\hline $80-\mathrm{NS}^{a}$ & $63.25 \pm 3.85^{\mathrm{ab}}$ & $0.16 \pm 0.09^{\mathrm{ab}}$ & & & $2.51 \pm 1.31^{\mathrm{a}}$ & $69.60 \pm 6.75^{b c}$ \\
\hline $80-S$ & $70.87 \pm 2.91^{b c}$ & $0.12 \pm 0.05^{\mathrm{ab}}$ & & & $13.9 \pm 1.79^{\mathrm{b}}$ & $64.97 \pm 9.71^{\mathrm{bc}}$ \\
\hline $100-\mathrm{NS}$ & $66.25 \pm 5.85^{\mathrm{ab}}$ & $0.33 \pm 0.10^{\mathrm{bc}}$ & & & $7.46 \pm 5.10^{\mathrm{ab}}$ & $79.09 \pm 3.61^{c}$ \\
\hline $100-S$ & $67.17 \pm 0.02^{\mathrm{ab}}$ & $0.48 \pm 0.02^{\mathrm{c}}$ & & & $6.15 \pm 0.39^{\mathrm{ab}}$ & $51.65 \pm 6.91^{\mathrm{a}}$ \\
\hline $120-\mathrm{NS}$ & $70.07 \pm 0.78^{b c}$ & $0.39 \pm 0.09^{b c}$ & & & $3.27 \pm 0.31^{\mathrm{a}}$ & $69.08 \pm 3.92^{\mathrm{b}}$ \\
\hline $120-\mathrm{S}$ & $73.46 \pm 0.08^{b c}$ & $0.40 \pm 0.01^{\mathrm{bc}}$ & & & $10.3 \pm 1.19^{\mathrm{ab}}$ & $54.01 \pm 2.20^{\mathrm{ab}}$ \\
\hline Pepeta & $71.60 \pm 7.41^{b c}$ & $0.37 \pm 0.11^{\mathrm{bc}}$ & & & $1.26 \pm 0.06^{\mathrm{a}}$ & $58.76 \pm 4.38^{\mathrm{abc}}$ \\
\hline Cooked rice & $85.90 \pm 7.44^{c}$ & $0.28 \pm 0.07^{\mathrm{abc}}$ & & & $3.73 \pm 4.17^{\mathrm{a}}$ & $77.85 \pm 3.91^{\mathrm{c}}$ \\
\hline Raw rice & $51.27 \pm 4.47^{\mathrm{a}}$ & $0.03 \pm 0.01^{\mathrm{a}}$ & & & $1.99 \pm 0.95^{\mathrm{a}}$ & $41.15 \pm 1.17^{\mathrm{a}}$ \\
\hline \multicolumn{7}{|l|}{26 DAH } \\
\hline 80-NS & $63.38 \pm 0.75^{b c}$ & $0.14 \pm 0.02^{\mathrm{ab}}$ & $72.23 \pm 0.05^{\mathrm{b}}$ & $0.30 \pm 0.04^{\mathrm{a}}$ & $14.7 \pm 6.01^{\mathrm{a}}$ & $60.76 \pm 7.50^{b c}$ \\
\hline $80-S$ & $55.13 \pm 1.39^{\mathrm{b}}$ & $0.20 \pm 0.09^{b c}$ & $70.85 \pm 4.10^{\mathrm{ab}}$ & $0.26 \pm 0.02^{\mathrm{a}}$ & $7.62 \pm 4.22^{\mathrm{a}}$ & $48.80 \pm 4.72^{\mathrm{ab}}$ \\
\hline $100-\mathrm{NS}$ & $72.67 \pm 3.23^{\mathrm{cd}}$ & $0.19 \pm 0.01^{\mathrm{ab}}$ & $75.83 \pm 2.63^{b}$ & $0.38 \pm 0.08^{\mathrm{a}}$ & $4.82 \pm 4.62^{\mathrm{a}}$ & $75.27 \pm 3.85^{\mathrm{cd}}$ \\
\hline $100-\mathrm{S}$ & $67.75 \pm 2.83^{c}$ & $0.12 \pm 0.02^{\mathrm{ab}}$ & $73.99 \pm 1.27^{b}$ & $0.41 \pm 0.11^{\mathrm{a}}$ & $2.77 \pm 0.37^{\mathrm{a}}$ & $60.63 \pm 4.24^{\mathrm{bc}}$ \\
\hline $120-\mathrm{S}$ & $77.84 \pm 1.90^{\mathrm{cd}}$ & $0.23 \pm 0.05^{b c}$ & $78.78 \pm 5.27^{b}$ & $0.47 \pm 0.14^{\mathrm{a}}$ & $4.11 \pm 1.81^{\mathrm{a}}$ & $51.63 \pm 4.52^{\mathrm{b}}$ \\
\hline $120-\mathrm{S}$ & $80.72 \pm 1.98^{\mathrm{d}}$ & $0.17 \pm 0.04^{\mathrm{ab}}$ & $80.55 \pm 3.56^{b}$ & $0.32 \pm 0.03^{\mathrm{a}}$ & $3.52 \pm 0.38^{\mathrm{a}}$ & $46.91 \pm 3.90^{\mathrm{ab}}$ \\
\hline Pepeta & $78.06 \pm 3.31^{\mathrm{d}}$ & $0.19 \pm 0.05^{b}$ & $77.25 \pm 1.87^{b}$ & $0.34 \pm 0.13^{\mathrm{a}}$ & $4.49 \pm 3.29^{\mathrm{a}}$ & $58.16 \pm 6.04^{\mathrm{b}}$ \\
\hline Cooked rice & $85.59 \pm 4.31^{\mathrm{d}}$ & $0.36 \pm 0.01^{\mathrm{c}}$ & $82.24 \pm 8.86^{b}$ & $0.82 \pm 0.64^{\mathrm{a}}$ & $15.0 \pm 3.74^{\mathrm{a}}$ & $89.95 \pm 3.37^{\mathrm{d}}$ \\
\hline Raw rice & $41.19 \pm 3.01^{\mathrm{a}}$ & $0.03 \pm 0.01^{\mathrm{a}}$ & $51.81 \pm 7.81^{\mathrm{a}}$ & $0.02 \pm 0.01^{\mathrm{b}}$ & $3.12 \pm 3.57^{\mathrm{a}}$ & $31.56 \pm 4.12^{\mathrm{a}}$ \\
\hline
\end{tabular}

${ }^{a} 80,100$ and 120 are roasting temperatures $\left({ }^{\circ} \mathrm{C}\right)$, NS - not soaked, $\mathrm{S}$ - soaked in cold water for $12 \mathrm{~h}$ before roasting. ${ }^{b}$ End of gastric and intestinal digestion, DAH - days after $50 \%$ heading, dwb - dry weight basis, $C_{\infty}$ - equilibrium hydrolysis, $k$ - rate constant, values in each column bearing

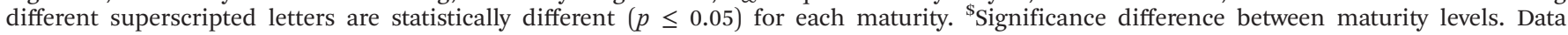
expressed as mean \pm standard deviation of two replicates. 


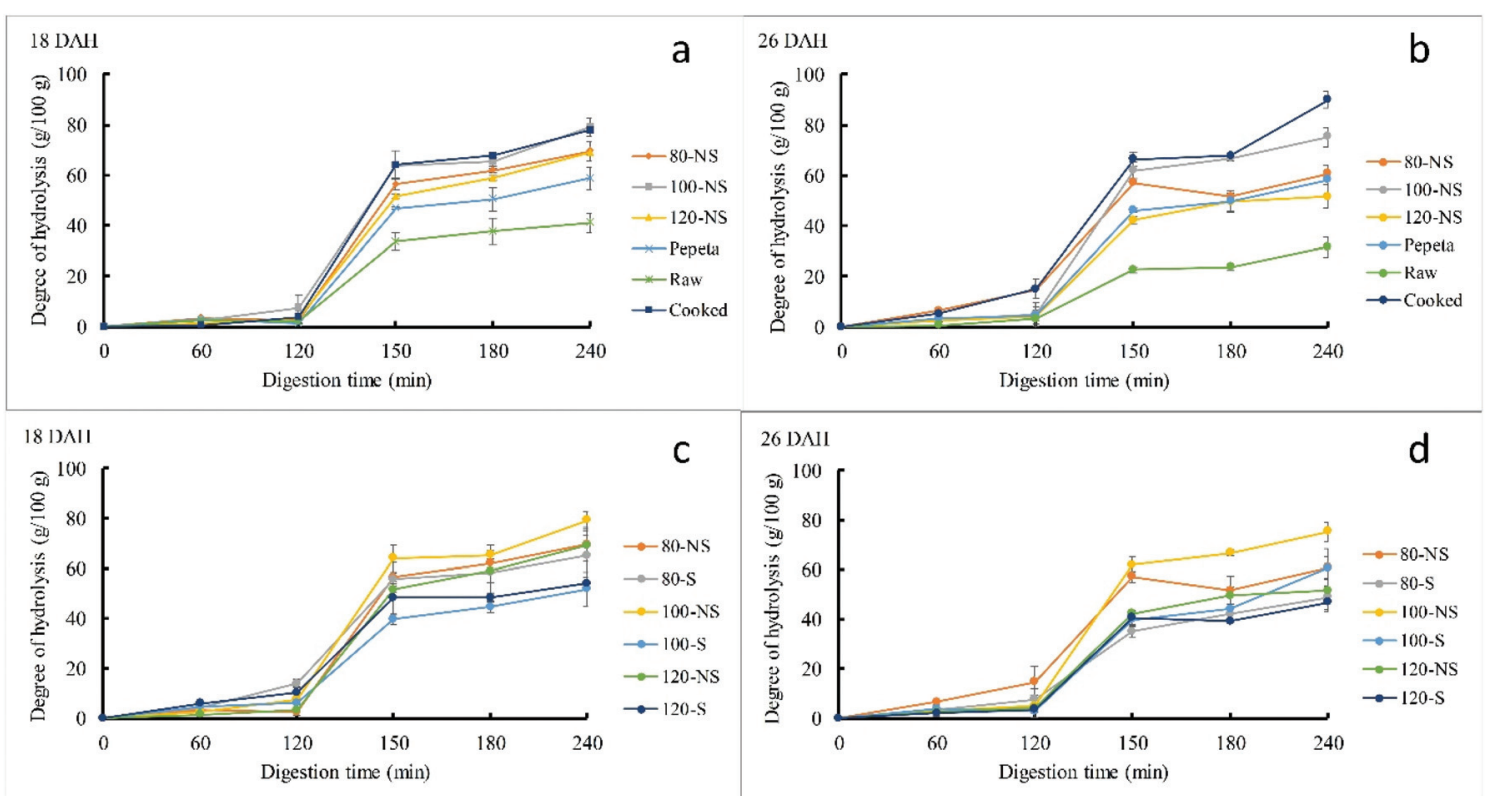

Fig. 6 In vitro hydrolysis of protein in TXD306 rice variety at two different stages of development (18 and 26 DAH - days after $50 \%$ heading) as affected by different processing conditions ( $a$ and $b$ ) and soaking before roasting (c and d). 80,100 and 120 are roasting temperatures $\left({ }^{\circ} \mathrm{C}\right.$ ), NS - not soaked, S - water-soaked rice at room temperature for $12 \mathrm{~h}$ prior roasting, pepeta - locally prepared rice flakes, raw - unprocessed rice, cooked cooked rice. Error bar represent standard deviation for means of two replicates.

standardized between $425-250 \mu \mathrm{m}$ while cooked rice grains were squeezed through $425 \mu \mathrm{m}$ sieve (section 2.2). Besides, the lack of cell wall structure in cooked rice particles (Fig. 4) could be why the observed high protein digestibility compared to roasted samples. Fig. 6 and Table 4 also indicates the mild roasting $\left(80\right.$ to $100{ }^{\circ} \mathrm{C}$ ) increased protein digestion compared to raw rice due to loss of tertiary structure, ${ }^{74}$ allowing exposure of peptide bonds to proteases. However, further increase in roasting temperature (at $120^{\circ} \mathrm{C}$ ) decreased the protein digestion, possibly due to highest formation of disulphide bonds (Fig. 7 panel b). Furthermore, the intense brown color at $120{ }^{\circ} \mathrm{C}$ (Fig. 1 panel A) suggests the formation of less digestible brown nitrogenous polymers, i.e., the melanoidins ${ }^{75,76}$ through Maillard reaction. Though soaking before roasting had no significant effect on the digestion of protein (except at $\left.100{ }^{\circ} \mathrm{C}, 18 \mathrm{DAH}\right)$, lower values at the end of intestinal digestion were observed in soaked products (Fig. 6 panels c and d) compared to unsoaked products, possibly due to slightly high disulphide bonds in soaked products (Fig. 7 panel b). Maturity level had no significant effect on the digestibility of protein between 18 and 16 DAH. Except for gastric digestion of protein at $18 \mathrm{DAH}$, no interaction effect was observed between soaking and roasting.

\subsection{Effect of heat treatment on rice protein aggregations}

To gain a thorough understanding of the changes in the digestibility of rice protein upon roasting (section 3.5.2), the effect of heat treatment on the heat-induced protein interactions and the relationship among heat-induced interactions and protein digestibility (Table 5) were investigated. The heat- induced protein interactions were monitored by comparison of protein solubility in different solvents meant to break specific physical interactions so that the differences indicate the contribution of those interactions to the gain in protein solubility. ${ }^{23}$ The analysis of free-thiol content and total thiol content (Fig. 7 panel c), and surface hydrophobicity (Fig. 7 panel d) were used to validate the protein solubility results.

As shown in Fig. 7 panels a and b, hydrophobic interactions and hydrogen bonds were involved in maintaining the structure of rice protein because the solubility in raw rice sharply increased in S2 and S3 solvent. Simultaneously, disulphide cross-linking plays a less important role, confirming the relative insolubility of rice proteins. ${ }^{24}$ The protein solubility in PBS (solvent S1) was significantly higher in raw rice and pepeta than roasted products and decreased with roasting temperature. Technically, the protein fractions soluble in the PBS buffer should be the albumin and globulin fractions, suggests that part of the albumin and globulin becomes insoluble after heat treatment, ${ }^{77}$ whereas the mechanical pounding immediately after roasting during pepeta preparation could influence the solubility of albumin and globulin fractions. The sharpest increase in protein solubility was observed at $80^{\circ} \mathrm{C}(55-58 \%)$ compared to raw rice $(36 \%)$ sample in solvent $\mathrm{S} 2$, indicating aggregations of proteins by hydrophobic interactions. The increase in protein solubility in solvent S2 was lower at 100 $(25-37 \%)$ and $120{ }^{\circ} \mathrm{C}(9-11 \%)$ compared to $80{ }^{\circ} \mathrm{C}$. Moreover, surface hydrophobicity (Fig. 7 panel d) increased significantly with roasting temperature, indicating the unfolding of proteins that expose hydrophobic parts of protein molecules. This may have facilitated the formation of aggregates through hydro- 


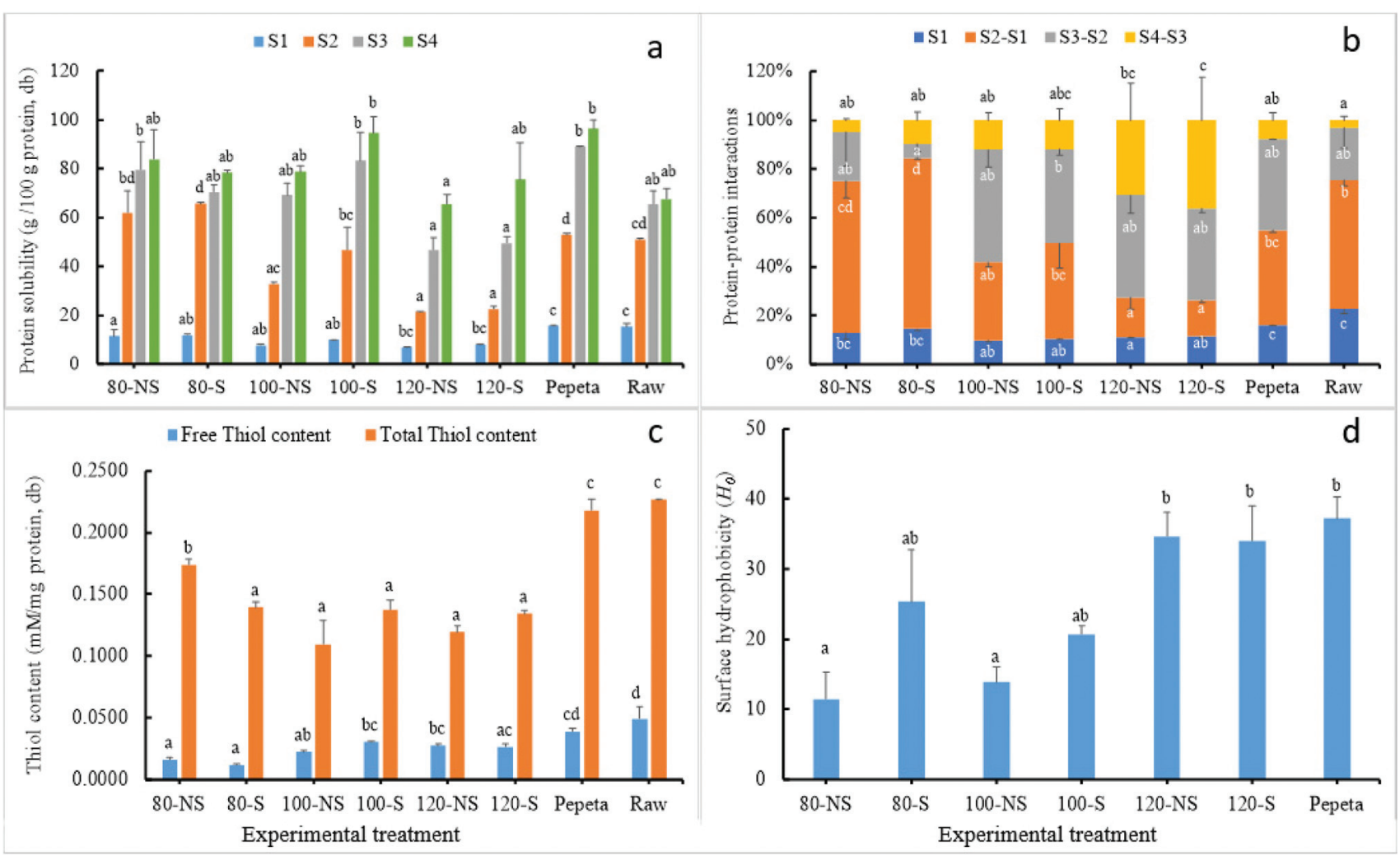

Fig. 7 Protein aggregations of rice protein subjected to different heat treatment conditions: (a) soluble protein recovery in 4 different solvents (S1: 0.1 M PBS (pH 7.5), S2: S1 + 2\% SDS ( pH 7.5), S3: S2 + 6 M urea (pH 7.5), S4: S3 + 1\% dithiothreitol ( $\mathrm{pH} 7.5)$; (b) changes in protein-protein interaction forces (S2-S1 = hydrophobic interactions, S3-S2 = hydrogen bonds, S4-S3 = disulfide bonds); (c) thiol content; and (d) protein surface hydrophobicity. 80, 100 and 120 indicate rice roasted at the corresponding temperatures $\left({ }^{\circ} \mathrm{C}\right), \mathrm{NS}-$ not soaked, $\mathrm{S}-$ water-soaked rice at room temperature for $12 \mathrm{~h}$ prior roasting, pepeta - locally prepared rice flakes, raw - unprocessed rice, db - dry basis. Labels with different letters indicate a statistically significant difference $(p \leq 0.05)$ across treatment conditions for each parameter. Each bar chart represents mean and standard deviation of two replicates. Positive error bars in (b) represent disulfide bonds, while negative error bars represent hydrophobic interactions and hydrogen bonds accordingly.

Table 5 The relationship between protein digestibility of rice subjected upon heat treatment and heat induced protein interactions at $26 \mathrm{DAH}$

\begin{tabular}{lll}
\hline & \multicolumn{2}{l}{$\begin{array}{l}\text { Gastrointestinal protein } \\
\text { digestion }\end{array}$} \\
\cline { 2 - 3 } Protein-protein interactions & $\begin{array}{l}\text { Pearson } \\
\text { correlation }\end{array}$ & $\begin{array}{l}P \text {-Value } \\
\text { (2-tailed) }\end{array}$ \\
\hline Native protein solubility & -0.571 & $\mathbf{0 . 0 2 1}$ \\
Hydrophobic interactions solubility & 0.066 & 0.809 \\
Hydrogen bonds solubility & 0.462 & 0.072 \\
Disulfide bonds solubility & -0.206 & 0.326 \\
Free thiols content & -0.421 & 0.105 \\
Total thiols content & -0.461 & 0.072 \\
Surface hydrophobicity & -0.620 & $\mathbf{0 . 0 1 0}$
\end{tabular}

$P$ values marked in bold fonts are significantly different $(p<0.05)$.

phobic interactions or $\mathrm{S}-\mathrm{S}$ bonds in roasted samples. ${ }^{77-79}$ However, the gain in protein solubility with solvent S2 was higher in samples roasted at lower temperatures suggesting that hydrophobic interactions were more critical in those samples. The protein solubility further increased in solvent S3 and S4, whereas a significant increase by $26 \%$ was observed in solvent S4 at $120{ }^{\circ} \mathrm{C}$ (Fig. 7 panel b), suggesting disulphide bond formation. In addition to this observation, the decrease of total thiol content after roasting suggests that some of the -SH moieties become irreversibly engaged in covalent bonds, suggesting the formation of covalently cross-linked aggregated proteins. However, we did not observe any clear effect of roasting temperature nor any obvious relation with protein digestibility (Table 5). Though soaking had no effect (except total thiols content at $80{ }^{\circ} \mathrm{C}$ ) on protein interactions, slightly high values at lower roasting temperatures ( 80 and $100{ }^{\circ} \mathrm{C}$ ) in free thiols content, surface hydrophobicity and hydrophobic interactions were observed in soaked samples compared with corresponding unsoaked samples. By contrast, high values of disulphide bonds in soaked samples were observed in high temperatures $\left(120{ }^{\circ} \mathrm{C}\right)$ as well. No interaction effect was observed between soaking and roasting except on free and total thiols contents. The solubility of pepeta protein was similar to that of roasted rice at $100{ }^{\circ} \mathrm{C}$. This was expected as pepeta was roasted at a temperature ranging from $80-120{ }^{\circ} \mathrm{C}$ (section 2.2). In general, the results indicate disulphide bonds 
played a vital role in heat-induced protein interactions of rice protein. However, only the native protein conformation and surface hydrophobicity negatively correlated significantly with protein digestibility (Table 5).

\section{Conclusion}

This study explored the effect of processing conditions to optimize the nutritional quality and digestibility properties of immature cereal-based products such as pepeta, a processed immature rice flake typically consumed in Tanzania. The increase in riboflavin, nicotinamide and iron in both locally and laboratory simulated pepeta products provide evidence of its potential nutritional benefits. The dietary fiber transformation from insoluble to soluble fiber was linked with an increase in roasting temperature, showing pepeta processing technology can enhance fiber functionality of immature ricebased products. In the same vein, the increase of starch digestibility with the severity of the processing conditions among roasted products indicates the possibility of manipulating roasting temperature to produce immature rice-based products with a more favorable glycemic response than cooked rice. On the contrary, the optimum roasting temperature is required for maximum protein digestibility due to observed different patterns as processing conditions changes. According to the data from this study, roasting at $100{ }^{\circ} \mathrm{C}$ is the optimum temperature to produce pepeta of high-quality digestible protein and low starch digestibility, both of which have health benefits. The digestibility of starch and protein was not affected by soaking before roasting, but the vitamin and mineral profile improved when a soaking step was introduced. Soaking before roasting at $120{ }^{\circ} \mathrm{C}$ is best for retaining micronutrients such as iron, riboflavin and nicotinamide. Though maturity had inconsistence effect on some of the assessed nutritional quality, a $26 \mathrm{DAH}$ is recommended over $18 \mathrm{DAH}$ when a low starch digestibility due to low hydrolysis rate constant $(k)$ is considered. Besides, the $26 \mathrm{DAH}$ would minimize rice yield loss as unfilled grains due to harvesting of immature rice, but this need further evaluation. In general, the study indicates that current pepeta processing technology can ensure a product with good nutritional properties but that the process can be optimized to further improve its nutritional quality.

\section{Author contributions}

Kulwa Furahisha Miraji: Conceptualization, data curation, formal analysis, investigation, methodology, visualization, writing - original draft, writing - review \& editing. Edoardo Capuano: Conceptualization, formal analysis, funding acquisition, methodology, project administration, supervision, writing - review \& editing. Vincenzo Fogliano: Conceptualization, funding acquisition, methodology, project administration, resources, supervision, writing - review \& editing. Henry Sarimbo Laswai: Formal analysis, methodology, supervision, visualization, writing - review \& editing. Anita R. Linnemann: Conceptualization, funding acquisition, methodology, project administration, resources, supervision, writing - review \& editing.

\section{Conflicts of interest}

The authors declare that they have no conflict of interest.

\section{Acknowledgements}

The authors are thankful to Ester Ferrusola Pastrana, Jeroen Post and Erik Meulenbroeks for helping to perform part of the experimental work. We are grateful to Wageningen Light Microscopy Center for the support in the confocal laser scanning microscopy analysis. We are also grateful for the assistance given by the Tanzania Agricultural Research Institute (TARI) Ifakara centre (formerly ARI-KATRIN), International Institute of Tropical Agriculture (IITA) - Dar es Salaam office, Village Agricultural and Extension Officers (VAEOs) and all the participants in Ulanga district during the collection of immature rice and pepeta samples and preparation of this article. This work was possible under the support of the Netherlands Fellowship Programme (grant award number CF13182/2017).

\section{References}

1 B. Özkaya, S. Turksoy, B. Baumgartner, İ. Özkeser and H. Koksel, Changes in the functional constituents and phytic acid contents of firiks produced from wheats at different maturation stages, Food Chem., 2018, 246, 150155.

2 M. Bayram, An analysis of scorched immature wheat: FREKEH, Cereal Foods World, 2008, 53(3), 134-138.

3 Ö. Özboy, B. Özkaya, H. Özkaya and H. Köksel, Effects of wheat maturation stage and cooking method on dietary fiber and phytic acid contents of firik, a wheat-based local food, Nahrung, 2001, 45(5), 347-349.

4 B. Özkaya, H. Özkaya, N. Eren, A. Ünsal and H. Köksel, Effects of wheat maturation stage and cooking method on physical and chemical properties of firiks, Food Chem., 1999, 66, 97-102.

5 P. Nkhabutlane, H. L. de Kock and d. R. GE, Culinary practices: preparation techniques and consumption of Basotho cereal breads in Lesotho, J. Ethn. Foods, 2019, 6(12), 1-11, DOI: 10.1186/s42779-019-0012-8.

6 K. F. Miraji, E. Capuano, V. Fogliano, H. S. Laswai and A. R. Linnemann, Utilization of Pepeta, a locally processed immature rice-based food product, to promote food security in Tanzania, PLoS One, 2021, 16(3), e0247870, DOI: 10.1371/journal.pone.0247870.

7 K. F. Miraji, A. R. Linnemann, V. Fogliano, H. S. Laswai and E. Capuano, Nutritional quality and in vitro digestion 
of immature rice-based processed products, Food Funct., 2020, 11, 7611-7625.

8 C. Ji, J. Shin, J. Cho and K. Lee, Nutritional Evaluation of Immature Grains in Two Korean Rice Cultivars during Maturation, Food Sci. Biotechnol., 2013, 22(4), 903-908.

9 R. Singh and B. O. Juliano, Free Sugars in Relation to Starch Accumulation in Developing Rice Grain, Plant Physiol., 1977, 29, 417-421.

10 S. Jiamyangyuen, N. Nuengchamnong and P. Ngamdee, Bioactivity and chemical components of Thai rice in five stages of grain development, J. Cereal Sci., 2017, 74, 136144.

11 P. Lin and H.-M. Lai, Bioactive compounds in rice during grain development, Food Chem., 2011, 127(1), 86-93.

12 O. Olsen, Endosperm development: Cellularization and Cell Fate Specification, Annu. Rev. Plant Physiol. Plant Mol. Biol., 2001, 52, 233-267.

13 A. Kumar, U. Sahoo, B. Baisakha, O. Augustine, U. Ngangkham, C. Parameswaran, et al., Resistant starch could be decisive in determining the glycemic index of rice cultivars, J. Cereal Sci., 2018, 79, 348-353.

14 J. Hu, C. La Vecchia, L. S. Augustin, E. Negri, G. M. De, H. Morrison, et al., Glycemic index, glycemic load and cancer risk, Ann. Oncol., 2013, 24, 245-251.

15 Y. Choi, E. Giovannucci and J. E. Lee, Review Article Glycaemic index and glycaemic load in relation to risk of diabetes-related cancers: a meta-analysis, Br. J. Nutr., 2012, 108, 1934-1947.

16 G. Kennedy, B. Burlingame and N. Nguyen, Nutrient impact assessment of rice in major rice-consuming countries, in International Rice Commission Newsletter, 51, 2002, pp. 33-42.

17 AOAC, Official Methods for Analysis, AOAC International, Gaithersburg, MD, 2000.

18 L. Amagliani, J. O. Regan, A. L. Kelly and J. A. O. Mahony, Journal of Food Composition and Analysis Composition and protein profile analysis of rice protein ingredients, J. Food Compos. Anal., 2017, 59, 18-26.

19 A. L. Matsler and T. J. Siebenmorgen, Evaluation of Operating Conditions for Surface Lipid Extraction from Rice Using a Soxtec System, Cereal Chem., 2005, 82(3), 282286.

20 I. Novozamsky, R. Van Eck, V. J. G. Houba and J. J. Van Der Lee, Solubilization of plant tissue with nitric acid-hydrofluoric acid-hydrogen peroxide in a closed-system microwave digestor, Commun. Soil Sci. Plant Anal., 1996, 27(3-4), 867-875.

21 C. Chen, Y. Yang, C. Shen, S. Lai, C. J. Chang and C. Shieh, Recovery of vitamins B from supercritical carbon dioxidedefatted rice bran powder using ultrasound water extraction, J. Taiwan Inst. Chem. Eng., 2011, 42, 124-128.

22 Z. A. Syahariza, E. Li and J. Hasjim, Extraction and dissolution of starch from rice and sorghum grains for accurate structural analysis, Carbohydr. Polym., 2010, 82, 14-20.

23 K. S. Liu and F. H. Hsieh, Protein-protein interactions during high-moisture extrusion for fibrous meat analogues and comparison of protein solubility methods using different solvent systems, J. Agric. Food Chem., 2008, 56(8), 2681-2687.

24 A. Van Der Borght, G. E. Vandeputte, V. Derycke, K. Brijs, G. Daenen and J. A. Delcour, Extractability and chromatographic separation of rice endosperm proteins, $J$. Cereal Sci., 2006, 44(1), 68-74.

25 K. Chan and B. P. Wasserman, Direct Colorimetric Assay of Free Thiol Groups and Disulfide Bonds in Suspensions of Solubilized and Particulate Cereal Proteins', Cereal Chem., 1993, 70(1), 22-26.

26 T. W. Thannhauser, Y. Konish and H. A. Scheraga, Analysis for Disulfide Bonds in Peptides and Proteins, Methods Enzymol., 1987, 143, 115-119.

27 S. W. Yin, C. H. Tang, Q. B. Wen, X. Q. Yang and L. Li, Functional properties and in vitro trypsin digestibility of red kidney bean (Phaseolus vulgaris L.) protein isolate: Effect of high-pressure treatment, Food Chem., 2008, 110(4), 938-945.

28 H. Wang, Y. Liu, L. Chen, X. Li, J. Wang and F. Xie, Insights into the multi-scale structure and digestibility of heatmoisture treated rice starch, Food Chem., 2018, 242, 323329.

29 M. Minekus, M. Alminger, P. Alvito, S. Ballance, T. Bohn, C. Bourlieu, et al., Function suitable for food - an international consensus, Food Funct., 2014, 5, 1113-1124.

30 M. Zahir, V. Fogliano and E. Capuano, Food matrix and processing modulate: In vitro protein digestibility in soybeans, Food Funct., 2018, 9, 6326-6336.

31 N. T. W. Cooper and T. J. Siebenmorgen, Correcting head rice yield for surface lipid content (Degree of Milling) variation, Cereal Chem., 2007, 84(1), 88-91.

32 J. I. Itoh, K. I. Nonomura, K. Ikeda, S. Yamaki, Y. Inukai, H. Yamagishi, et al., Rice plant development: From zygote to spikelet, Plant Cell Physiol., 2005, 46(1), 23-47.

33 H. Xu, W. Zhang, Y. Gao, Y. Zhao, L. Guo and J. Wang, Proteomic analysis of embryo development in rice (Oryza sativa), Planta, 2012, 235(4), 687-701.

34 Z. Y. Deng, C. Y. Gong and T. Wang, Use of proteomics to understand seed development in rice, Proteomics, 2013, 13(13), 1784-1800.

35 C. Hu, T. Tohge, S. A. Chan, Y. Song, J. Rao, B. Cui, et al., Identification of Conserved and Diverse Metabolic Shifts during Rice Grain Development, Sci. Rep., 2016, 6, 20942.

36 T. Kawakatsu and F. Takaiwa, Rice proteins and essential amino acids, in Rice: Chemistry and Technology, ed. J. Bao, AACC International Press, Cambridge, MA, 4th edn, 2019, pp. $109-130$.

37 B. O. Juliano and A. P. P. Tuaño, Gross structure and composition of the rice grain, in Rice: Chemistry and Technology, ed. J. Bao, AACC International Press, Cambridge, MA, 4th edn, 2019, pp. 31-53.

38 L. J. Cruz, G. B. Cagampang and B. O. Juliano, Biochemical Factors Affecting Protein Accumulation in the Rice Grain, Plant Physiol., 1970, 46(5), 743-747. 
39 H. Bader Ul Ain, F. Saeed, A. Ahmed, M. Asif Khan, B. Niaz and T. Tufail, Improving the physicochemical properties of partially enhanced soluble dietary fiber through innovative techniques: A coherent review, J. Food Process. Preserv., 2019, 43(4), 1-12.

40 A. M. van Bennekum, D. V. Nguyen, G. Schulthess, H. Hauser and M. C. Phillips, Mechanisms of cholesterollowering effects of dietary insoluble fibres: relationships with intestinal and hepatic cholesterol parameters, Br. J. Nutr., 2005, 94(3), 331-337.

41 S. Naumann, U. Schweiggert-Weisz, A. Martin, M. Schuster and P. Eisner, Effects of extrusion processing on the physiochemical and functional properties of lupin kernel fibre, Food Hydrocolloids, 2021, 111, 106222.

42 E. Capuano, The behavior of dietary fiber in the gastrointestinal tract determines its physiological effect, Crit. Rev. Food Sci. Nutr., 2017, 57(16), 3543-3564.

43 Y. M. Cassidy, E. M. McSorley and P. J. Allsopp, Effect of soluble dietary fibre on postprandial blood glucose response and its potential as a functional food ingredient, J. Funct. Foods, 2018, 46, 423-439.

44 B. Wolf, Polysaccharide functionality through extrusion processing, Curr. Opin. Colloid Interface Sci., 2010, 15(1-2), 50-54.

45 R. J. Redgwell, D. Curti, F. Robin, L. Donato and N. Pineau, Extrusion-induced changes to the chemical profile and viscosity generating properties of citrus fiber, J. Agric. Food Chem., 2011, 59(15), 8272-8279.

46 T. T. Dang and T. Vasanthan, Modification of rice bran dietary fiber concentrates using enzyme and extrusion cooking, Food Hydrocolloids, 2019, 89, 773-782.

47 V. M. Butardo, N. Sreenivasulu and B. O. Juliano, Rice grain quality: State of the art and future prospects, in Rice grain quality: Methods and protocols, Humana Press, 2019.

$48 \mathrm{~K}$. Bhattacharya, Rice quality: a guide to rice properties and analysis, Woodhead Publishing Ltd, Cambridge, UK, 2011, 562 p.

49 J. Manful, A. Swetman, R. Coker and A. Drunis, Changes in the thiamine and ribofl avin contents of rice during artisanal parboiling in Ghana, Trop. Sci., 2007, 47(4), 211-217.

50 P. Oli, R. Ward, B. Adhikari and P. Torley, Parboiled rice: Understanding from a materials science approach, J. Food Eng., 2014, 124, 173-183.

51 A. B. Padua and B. O. Juliano, Effect of parboiling on thiamin, protein and fat of rice, J. Sci. Food Agric., 1974, 25(6), 697-701.

52 H. Watanabe, M. Fukuoka, A. Tomiya and T. Mihori, A new non-Fickian diffusion model for water migration in starchy food during cooking, J. Food Eng., 2001, 49(1), 1-6.

53 P. Oli, R. Ward, B. Adhikari and P. Torley, The Diffusion of Moisture in Paddy During Hydration and Dehydration Processes, Drying Technol., 2014, 32(12), 1423-1434.

54 A. Matsui, Y. Yin, K. Yamanaka, M. Iwasaki and H. Ashihara, Metabolic fate of nicotinamide in higher plants, Physiol. Plant., 2007, 131(2), 191-200.

55 S. E. Bocobza, S. Malitsky, W. L. Araújo, A. Nunes-Nesi, S. Meir, M. Shapira, et al., Orchestration of thiamin biosynthesis and central metabolism by combined action of the thiamin pyrophosphate riboswitch and the circadian clock in Arabidopsis, Plant Cell, 2013, 25(1), 288-307.

56 J. A. Miret and S. Munné-Bosch, Plant amino acid-derived vitamins: Biosynthesis and function, Amino Acids, 2014, 46(4), 809-824.

57 P. V. S. Rao and K. R. Bhattacharya, Effect of Parboiling on Thiamine Content of Rice, J. Agric. Food Chem., 1966, 14(5), 479-482.

58 P. Sahni, S. Sharma and B. Singh, Impact of different processing treatments on techno and biofunctional characteristics of dhaincha (Sesbania aculeate), Food Sci. Technol. Int., 2021, 27(3), 251-263.

59 L. Jing, L. Yuwei, H. Zhenping and W. Qian, Impact of heat processing on the bioavailability of zinc and iron from cereals and pulses, Int. Food Res. J., 2017, 24(5), 1980-1985.

60 M. Carbonaro, G. Lombardi-Boccia and E. Carnovale, Influence of the method of protein extraction on the in vitro evaluation of mineral dialysability from legumes, Food Chem., 1995, 53(3), 249-252.

61 Y. W. Luo, W. H. Xie, X. X. Jin, Q. Wang and Y. J. He, Effects of germination on iron, zinc, calcium, manganese, and copper availability from cereals and legumes, CyTA-J. Food, 2014, 12(1), 22-26.

62 Y. Luo, W. Xie and F. Luo, Effect of Several Germination Treatments on Phosphatases Activities and Degradation of Phytate in Faba Bean (Vicia faba L.) and Azuki Bean (Vigna angularis L.), J. Food Sci., 2012, 77(10), C1023-C1029.

63 S. Bhosale and D. Vijayalakshmi, Processing and nutritional composition of rice bran, Curr. Res. Nutr. Food Sci., 2015, 3(1), 74-80.

64 T. A. Zafar, High amylose cornstarch preloads stabilized postprandial blood glucose but failed to reduce satiety or food intake in healthy women, Appetite, 2018, 131, 1-6.

65 H. Li, Y. Wen, J. Wang and B. Sun, The molecular structures of leached starch during rice cooking are controlled by thermodynamic effects, rather than kinetic effects, Food Hydrocolloids, 2017, 73, 295-299.

66 M. Tamura and Y. Ogawa, Visualization of the coated layer at the surface of rice grain cooked with varying amounts of cooking water, J. Cereal Sci., 2012, 56, 404-409.

67 P. Oli, R. Ward, B. Adhikari and P. Torley, Effect of barrier layers and gelatinisation processes on mass water diffusion into the paddy grain, in Parboiled rice: understanding from a material science approach, Charles Sturt University, Wagga Wagga, 1st edn, 2016, pp. 39-71.

68 S. Sayar, M. Turhan and S. Gunasekaran, Analysis of chickpea soaking by simultaneous water transfer and waterstarch reaction, J. Food Eng., 2001, 50(2), 91-98.

69 M. R. Toutounji, A. Farahnaky, A. B. Santhakumar, P. Oli, V. M. Butardo and C. L. Blanchard, Intrinsic and extrinsic factors affecting rice starch digestibility, Trends Food Sci. Technol., 2019, 88, 10-22.

70 A. M. Rovalino-córdova, V. Fogliano and E. Capuano, A closer look to cell structural barriers a ff ecting starch 
digestibility in beans, Carbohydr. Polym., 2018, 181, 9941002.

71 A. M. Rovalino-córdova, V. Fogliano and E. Capuano, The effect of cell wall encapsulation on macronutrients digestion: A case study in kidney beans, Food Chem., 2019, 286, 557-566.

72 M. Chitra, Effect of processing paddy on digestibility of rice starch by in vitro studies, J. Food Sci. Technol., 2010, 47, 414-419.

73 H. Dutta, C. Lata, V. Singh, B. Baruah and N. Rahman, Physical, physicochemical and nutritional characteristics of Bhoja chaul, a traditional ready-to-eat dry heat parboiled rice product processed by an improvised soaking technique, Food Chem., 2016, 191, 152-162.

74 M. Zhao, W. Xiong, B. Chen, J. Zhu and L. Wang, Enhancing the solubility and foam ability of rice glutelin by heat treatment at $\mathrm{pH} 12$ : Insight into protein structure, Food Hydrocolloids, 2020, 103, 105626.
75 J. Liu, Q. Ru and Y. Ding, Glycation a promising method for food protein modification: Physicochemical properties and structure, a review, Food Res. Int., 2012, 49(1), 170-183.

76 J. M. Silván, F. J. Morales and F. Saura-Calixto, Conceptual study on maillardized dietary fiber in coffee, J. Agric. Food Chem., 2010, 58(23), 12244-12249.

77 K. Liu, J. Zheng and F. Chen, Heat-induced changes in the physicochemical properties and in vitro digestibility of rice protein fractions, J. Food Sci. Technol., 2021, 58, 13681377.

78 L. Jiang, Z. Wang, Y. Li, X. Meng, X. Sui, B. Qi, et al., Relationship between surface hydrophobicity and structure of soy protein isolate subjected to different ionic strength, Int. J. Food Prop., 2015, 18(5), 1059-1074.

79 J. M. Wang, N. Xia, X. Q. Yang, S. W. Yin, J. R. Qi, X. T. He, et al., Adsorption and dilatational rheology of heat-treated soy protein at the oil-water interface: Relationship to structural properties, J. Agric. Food Chem., 2012, 60(12), 3302-3310. 